University of Pennsylvania Carey Law School

Penn Law: Legal Scholarship Repository

Faculty Scholarship at Penn Law

2002

\title{
The Paradox of Delegation: Interpreting the Federal Rules of Civil Procedure
}

Catherine T. Struve

University of Pennsylvania Carey Law School

Follow this and additional works at: https://scholarship.law.upenn.edu/faculty_scholarship

Part of the Civil Procedure Commons, Courts Commons, Jurisprudence Commons, and the Legal History Commons

\section{Repository Citation}

Struve, Catherine T., "The Paradox of Delegation: Interpreting the Federal Rules of Civil Procedure" (2002). Faculty Scholarship at Penn Law. 1189.

https://scholarship.law.upenn.edu/faculty_scholarship/1189

This Article is brought to you for free and open access by Penn Law: Legal Scholarship Repository. It has been accepted for inclusion in Faculty Scholarship at Penn Law by an authorized administrator of Penn Law: Legal Scholarship Repository. For more information, please contact PennlawIR@law.upenn.edu. 


\section{University of Pennsylvania Law Review

\author{
FOUNDED 1852
}

Formerly

American Law Register

\section{ARTICLES}

\section{THE PARADOX OF DELEGATION: INTERPRETING THE FEDERAL RULES OF CIVIL PROCEDURE}

\section{CATHERINE T. STRUVE ${ }^{\dagger}$}

INTRODUCTION

I. THE RULEMAKING STRUCTURE............................................ 1103

A. Overview of the Current Process ........................................ 1103

B. Multiple Decision Makers .............................................1105

C. Representation ........................................................1109

D. Public Access and Input ............................................1110

E. The Advisory Committee Notes .......................................1112

F. The Report-and-Wait Requirement................................1115

\footnotetext{
'Assistant Professor, University of Pennsylvania Law School. I thank Stephen Burbank, William Ewald, Frank Goodman, Geoffrey Hazard, Stephen Morse, Stephen Perry, James Pfander, Edward Rubin, and Amy Wax for their extremely helpful comments on previous drafts. This paper has also benefited greatly from comments by participants in a University of Pennsylvania Law School Faculty Retreat. Thanks, as well, to the University of Pennsylvania Law Review for their excellent editorial work, and to Ronald Day and the staff of the Biddle Law Library for their invaluable assistance. Remaining errors are mine alone.
} 
II. Delegation AND Discretion.

A. The Rules Enabling Act's Conditional Transfer of Power.

B. The Responsive Nature of the Rulemaking Process

C. Other Advantages of the Rulemaking Process.

III. DELEGATION AND INTERPRETIVE SOURCES.

A. The Limits of the Delegation ...........................................1147

B. Advisory Committee Notes

1. Intentionalism and the Notes.

2. Textualism and the Notes

3. The Court's Use of the Notes and Comparable Materials

\section{INTRODUCTION}

Distinctions between the functions of the legislative and judicial branches are a staple of debates over statutory interpretation. To some, the fact that federal judges have no vote in the legislative process supports the argument that a court should implement a statute's text even when the court's policy inclinations counsel otherwise. In the view of others, courts can complement Congress's work, for instance by updating obsolete statutes that remain on the books through congressional inattention or inertia. In such discussions, the question of a court's authority-or lack thereof-to alter a statutory text through interpretation implicates a familiar problem of political theory: the scope of the judicial power and its relation to the legislative power.

Far less attention has been given, however, to courts' interpretation of texts crafted by the judicial branch itself. Pursuant to congressional delegation of authority, the federal judiciary has promulgated various sets of rules governing civil, criminal, appellate, bankruptcy and habeas practice. Although some have discussed the implications of this delegation for the interpretation of the Federal Rules of Evidence, 'few scholars have addressed the interpretation of other sets of

\footnotetext{
See, e.g., Edward J. Imwinkelried, Moving Beyond "Top Down" Grand Theories of Statutory Construction: A "Bottom Up" Interpretive Approach to the Federal Rules of Evidence, 75 OR. L. REV. 389, $394-95$ (1996) (arguing that interpreters of the Evidence Rules should give "heightened emphasis" to text and "significant weight" to Advisory Committee Notes); Randolph N. Jonakait, The Supreme Court, Plain Meaning, and the Changed Rules of Evidence, 68 TEX. L. REV. 745, 784-86 (1990) (predicting that a "plain meaning" approach to interpretation of the Evidence Rules will prevent judges from "adapt[ing] evidence law to new knowledge and conditions"); Eileen A. Scallen \& Andrew E. Tas-
} 
rules, such as the Federal Rules of Civil Procedure. ${ }^{2}$ This omission is notable because many aspects of the Civil Rules have a wider and more direct effect on judicial power than do the Rules of Evidence. Moreover, those who have addressed the interpretation of the Civil Rules tend to take as a given that, because Congress has delegated rulemaking power to the judiciary, the courts should be able freely to interpret, and alter, the resulting Rules. Thus, the two most extensive scholarly discussions to date on the subject of the Civil Rules argue that the Supreme Court's role in promulgating the Rules empowers it to use a more dynamic approach in interpreting them.' For example, Karen Nelson Moore argues that "Congress has ... delegated to the Court rulemaking power, and it is not inconsistent to imply that the Court has greater power to interpret Rules than it does to interpret statutes"; accordingly, Judge Moore maintains, the Court should consider itself free to play a "formative role" in "develop[ing]" the Rules in light of its views of purpose and policy. A similar assumption appears to have influenced the behavior of some lower courts. For example, as discussed below, Judges Posner, Easterbrook, and others

litz, Reading the Federal Rules of Evidence Realistically: A Response to Professor Imwinkelried, 75 OR. L. REV. 429, 435 (1996) (defending "hermeneutic and practical reasoning approaches" to interpretation of the Evidence Rules).

2 Interpretation of the Civil Rules presents issues distinct from those that arise with respect to the Evidence Rules. See Edward J. Imwinkelried, Whether the Federal Rules of Evidence Should Be Conceived as a Perpetual Index Code: Blindness Is Worse Than Myopia, 40 WM. \& MARY L. REV. 1595, 1599 (1999) (criticizing an "analogy to the experience with the Federal Rules of Civil Procedure" as "inapt in the extreme"). Although a set of proposed Evidence Rules was drafted in the early 1970s pursuant to the Enabling Act delegation, Congress passed legislation to block the proposals from taking effect and ultimately enacted the Rules of Evidence via legislation that made substantive changes to some of the original proposals and stylistic changes to others. See infra note 16 (describing the process by which Congress enacted the Federal Rules of Evidence). By contrast, the vast majority of the Civil Rules were neither promulgated nor amended via legislation; and because a central theme of this Article is the significance of the rulemaking process to the Rules' interpretation, the scholarship on the Evidence Rules is thus largely inapposite.

${ }^{3}$ See Joseph P. Bauer, Schiavone: An Un-Fortune-ate Illustration of the Supreme Court's Role as Interpreter of the Federal Rules of Civil Procedure, 63 NOTRE DAME L. REV. 720,720 (1988) (arguing that because the Supreme Court promulgates the Rules, federal courts are "fully justified in taking an expansive view of the Federal Rule under scrutiny, giving it a liberal reading if that is required to fulfill the purposes of the Rule or to do justice between the parties before the court"); Karen Nelson Moore, The Supreme Court's Role in Interpreting the Federal Rules of Civil Procedure, 44 HASTINGS L.J. 1039, 1093 (1993) ("Given [the] substantial, although largely unexercised, powers of the Court in the promulgation process, a more activist role in the interpretative stage, one that considers purpose and policy, is appropriate.").

Moore, supra note 3, at 1093, 1097. 
engaged in a striking judicial amendment of the 1983 version of Rule 11 , with dramatic implications for the conduct of litigation in the Seventh Circuit.

Although the view described above may appear to be a truism, I shall argue that-paradoxically-Congress's delegation of rulemaking authority should constrain, rather than liberate, courts' interpretation of the Rules. I begin, in Part I, with a discussion of the rulemaking process. Under the current structure, an amendment cannot become law unless it receives the support of several decision-making bodies, including the Supreme Court, and unless Congress takes no action (during a specified period) to prevent the amendment from going into effect. The enabling legislation ensures that lower court judges and members of the public are represented in some of the decisionmaking bodies, mandates public access to the rulemaking meetings, and requires that proposed amendments be accompanied by explanatory notes. The public receives an opportunity to comment on proposed amendments, and the proposals are sometimes modified in response to public input. In Part II, I argue that these features of the rulemaking process constrain any subsequent interpretation of the Rules: the terms of the delegation make clear that alterations to the Rules should undergo the process specified in the Enabling Act, rather than taking effect through judicial fiat in the course of litigation.

Of course, my arguments against judicial "alteration" of the Rules are not meant to suggest that the Rules will in all instances have a determinate meaning that is evident across time and to all interpreters. Where appropriate interpretive guides define a Rule's meaning, however, I contend that judges should adhere to that definition. In Part III, I discuss two possible interpretive guides: the Enabling Act's scope restriction and the Advisory Committee Notes ("Notes"). The Enabling Act prohibits the Rules from abridging, enlarging, or modifying substantive rights; the Court, however, has never enforced this restriction directly by invalidating a Rule. Instead, the Court gives the Rules a presumption of validity, but construes them so as to avoid some of the resulting Enabling Act problems. This avoidance canon, in its weak form, can help guide the Court's choice between two otherwise permissible interpretations of a Rule. I argue, however, that the Court's application of the avoidance canon in its strong form-to revise a Rule in the face of its text and Note-cannot be justified in light of the Enabling Act framework. That framework also underpins my assessment of the Court's approach to the Advisory Committee Notes. 
Although the Court repeatedly makes use of the Notes, as yet it has been unwilling to concede that it might be bound by them. After reviewing the Court's treatment of the Notes and comparing the Court's deference to the commentary to the United States Sentencing Guidelines, and to agency interpretations of legislative rules, I conclude that the Court should accord the Notes authoritative effect.

To illustrate these arguments, Parts II and III consider in some detail several aspects of the interpretation and amendment of Rule 11 over the past two decades. These examples, I argue, demonstrate the difficulties with judicial claims to latitude in interpreting the Rules and suggest that my proposed approach would help to prevent courts from unduly enlarging the scope of their interpretive powers.

\section{The RULEMAKING STRUCTURE}

The rules enabling legislation, in its present form, imposes significant procedural requirements on the promulgation of a Rule or amendment. This Part gives an overview of the current process and highlights five key features: the requirement of approval by multiple bodies; the representation (within the decision-making structure) of several different constituencies; the opportunity for public notice and comment; the use of explanatory Notes to inform the consideration of a proposed amendment; and the report-and-wait period for congressional review. In each of these respects, Congress increasingly has placed statutory constraints on the Supreme Court's rulemaking discretion. I will argue in Parts II and III that these constraints place corresponding restrictions on the Court's ability to amend the resulting Rules through interpretation.

\section{A. Overview of the Current Process}

A proposed new Rule, or a proposed amendment to an existing Rule, undergoes at least seven stages of formal comment and review, in a process involving five separate institutions: the Advisory Committee on Civil Rules, the Standing Committee on Rules of Practice and Procedure, the Judicial Conference of the United States, the Supreme Court, and Congress. The normal procedure is as follows. Proposed changes-which may be suggested by anyone, including judges, practitioners, academics, and interested members of the public-are analyzed by the Advisory Committee Reporter, who submits the suggestions to the Advisory Committee along with a recommendation for disposition. The Committee (at its next biannual meeting) then con- 
siders whether to accept, reject, or defer action on each suggestion. If the Committee accepts the suggestion, it asks the Reporter to prepare a proposed draft amendment and an explanatory note. The Advisory Committee then votes on the proposed amendment and its Note, and (if it approves) seeks permission from the Standing Committee to publish the proposal..$^{5}$ Once permission is received, the proposed amendment and Note are circulated for public comment. Following the comment period, the Advisory Committee reconsiders the proposal in light of the public's input. ${ }^{6}$ Once the Advisory Committee finally approves the proposed amendment and Note, it submits them to the Standing Committee. If the Standing Committee approves the proposal without substantial changes, it forwards the proposed amendment and Note to the Judicial Conference. ${ }^{7}$ Proposals forwarded by the Standing Committee are considered by the Judicial Conference once a year; the Conference, if it approves a proposal, transmits it to the Supreme Court. If the Supreme Court, in turn, approves the proposal, the Chief Justice forwards the amendment's text and Note to Congress by May 1 of the year in which the amendment is to take effect. If Congress takes no contrary action, the proposed amendment becomes effective on December 1 .

\footnotetext{
"In some instances, permission may be sought from the chair of the Standing Committee.

"If the Advisory Committee makes substantial changes, it may provide additional opportunity for public comment.

${ }^{7}$ If the Standing Committee makes a substantial change to the proposal, it may return the proposal to the Advisory Committee for further consideration. Sometimes, however, it forwards the proposal to the Judicial Conference despite making a significant change. Thus, in 1992 the Standing Committee amended the text of the proposed Rule 11 to remove the requirement of mandatory sanctions, and to eliminate any duty to withdraw a previously filed paper, and recommended that the Judicial Conference approve the amended proposal. See Judicial CONFERENCE COMM. ON Rules of Practice and PRODCEDURE, EXCERPT From the REPORT TO THE CHIEF JUSTICE OF THE UNITED STATES AND MEMBERS OF THE JUdiCiAl CONFERENCE OF THE UNITED STATES (Sept. 1992), in 146 F.R.D. 515, 517 (1993) (describing the Standing Committee's changes to the Advisory Committee's proposed amendments to Rule 11 , and stating the Standing Committee's view that these changes "do not ... require another period of publication and comment"); id. at 518 (recommending that the Judicial Conference approve the proposed amendments to, inter alia, Rule 11). (The Advisory Committee's original proposal had been criticized for including the duty to withdraw papers. See A. Leon Higcinbotham, JR., ET al., Bench-Bar Proposal to Revise CIVIL Procedure RULE 11, at 1, reprinted in 137 F.R.D. 159, 162 (1991) (arguing that the Advisory Committee's proposal "turns a law suit not into a prospective search for the truth but into a retroactive exercise in perfecting pleadings").)
} 


\section{B. Multiple Decision Makers}

The process did not always involve so many stages of review. The original delegation, in the Rules Enabling Act of 1934, identified only two decision makers: the Court (which was to promulgate the Rules) and-implicitly-Congress (which was to have an opportunity to prevent the Rules from taking effect). Congress added a further layer in 1958 (when it directed the Judicial Conference to consider proposed changes to the Rules) and formally mandated two more layers in 1988 (when it required the involvement of the Standing Committee and set rules for the composition of any Advisory Committees). The history thus discloses a trend away from unilateral Supreme Court decision making and toward a process that includes multiple gatekeepers.

The Rules Enabling Act of 1934 authorized the Supreme Court to prescribe general rules for civil practice and procedure in the federal district courts, so long as the Rules did not "abridge, enlarge, [or] modify the substantive rights of any litigant." 8 The Act said little concerning the procedure for promulgation, requiring only that the Rules be reported to Congress at the beginning of a regular session and that they not take effect until after the close of that session.'

${ }^{8}$ Act of June 19, 1934, 651, Pub. L. No. 73-415, § 1, 48 Stat. 1064, 1064. Rules merging law and equity practices were subject to the additional requirement that they preserve the right of trial by jury. See id. $\$ 2,48$ Stat. at 1064 (providing that "in such union of rules the right of trial by jury ... shall be preserved").

${ }^{9}$ Section 1 of the Act provided:

[T] he Supreme Court of the United States shall have the power to prescribe, by general rules, for the district courts of the United States and for the courts of the District of Columbia, the forms of process, writs, pleadings, and motions, and the practice and procedure in civil actions at law. Said rules shall neither abridge, enlarge, nor modify the substantive rights of any litigant. They shall take effect six months after their promulgation, and thereafter all laws in conflict therewith shall be of no further force or effect.

Id. $\S 1,48$ Stat. at 1064 .

Section 2 permitted the Court to "unite the general rules prescribed by it for cases in equity with those in actions at law so as to secure one form of civil action and procedure for both," but provided that "[s] uch united rules shall not take effect until they shall have been reported to Congress by the Attorney General at the beginning of a regular session thereof and until after the close of such session." Id. $\$ 2,48$ Stat. at 1064. The Federal Rules of Civil Procedure, of course, merged law and equity procedures, see FED. R. CIV. P. 1 (providing that the Civil Rules govern federal district court procedure in all civil suits, subject to specified exceptions); FED. R. CIV. P. 2 (instituting a single form of action), and the Court requested the transmission of the proposed Rules to Congress as required by the report-and-wait procedure prescribed in section 2 of the Act, see Order of Dec. 20, 1937, 302 U.S. 783, 783 (promulgating the Rules "pursuant to Section 2" of the Enabling Act, and directing the Chief Justice to request that the Attorney General report the Rules to Congress); Order of Jan. 17, 1938, 302 U.S. 
For the next two decades, the Court employed an Advisory Committee to draft proposed Rules and amendments, which the Court ordinarily transmitted to Congress. ${ }^{10}$ Occasionally, the Court rejected rules proposed by the Committee; ${ }^{11}$ in one instance the Court promulgated a Rule on its own initiative.

The formality of the drafting and approval process increased in

783,784 (noting that the Rules had been submitted to Congress).

The timing changed somewhat in 1950 , when the Act was amended to specify a ninety-day report-and-wait period. See Act of May 10, 1950, Pub. L. No. 81-510, § 2, 64 Stat. 158, 158 (establishing the ninety-day report-and-wait period).

${ }^{10}$ In 1935, the Court appointed a group of fourteen lawyers and academics as an Advisory Committee to "assist" the Court in preparing the initial set of Rules. See Order of June 3, 1935, 295 U.S. 774, 774-75 (appointing the members of the Advisory Committee). In 1942, the Court designated the Committee as a continuing body, see Order of January 5, 1942, 314 U.S. 720, 720 (providing for a continuing Advisory Committee to advise the Court on proposed amendments or additions to the Federal Rules of Civil Procedure), and the Committee continued in its advisory role until the Court discharged it in 1956, see Order of Oct. 1, 1956, 352 U.S. 803, 803 (discharging the Advisory Committee and revoking the order making the Committee a continuing body).

See Stephen B. Burbank, The Rules Enabling Act of 1934, 130 U. PA. L. REV. 1015, 1139 (1982) (noting the Supreme Court's alteration of a draft rule on evidence that the Advisory Committee had proposed in 1937); id. at 1144-45 (describing the Supreme Court's deletion of a draft rule on registration of judgments that the Advisory Committee had proposed in 1937); Charles E. Clark, The Federal Rules of Civil Procedure, 1938-1958: Two Decades of the Federal Civil Rules, 58 COLUM. L. REV. 435, 442 (1958) [hereinafter Clark, Federal Rules] (noting the Supreme Court's rejection, in 1948, of three proposed rules, each of which "presented a problem then before the Court in a particular case"); id. at 442 \& n.36 (noting that in 1948 the Supreme Court directed the Advisory Committee to reconsider a proposed rule concerning condemnation proceedings and stating that the subsequent changes in the resulting Rule were "thus due to the direct control of the Court"); Charles E. Clark, The Role of the Supreme Court in Federal Rule-Making, 46 AM. JUD. SOC. 250, 252 (1963) [hereinafter Clark, Role of the Supreme Court] (stating that after proposals made by the Advisory Committee in 1955 "had provoked discussion and some controversy," the Court discharged the Committee and "took no action" on the proposed rules, but that the Court eventually adopted some of these proposals, with revisions, in 1963); Jack H. Friedenthal, The Rulemaking Power of the Supreme Court: A Contemporary Crisis, 27 STAN. L. REV. 673, 677 (1975) ("Although the Justices generally deferred to the [Advisory] Committee's expertise during [the period from 1935 to 1956], they at least read and, when appropriate, rejected proposed alterations.").

${ }^{12}$ In 1956, "the Court, acting on its own and without recommendation of any committee," amended Rule 46 of the Federal Rules of Criminal Procedure. Clark, Role of the Supreme Court, supra note 11, at 257. This amendment was adopted pursuant to a separate enabling act, then codified at 18 U.S.C. $\$ 3771$ (repealed 1988), authorizing the promulgation of certain criminal rules. Although the criminal and civil rules enabling acts were not merged until 1988, see Judicial Improvements and Access to Justice Act, Pub. L. No. 100-702, tit. IV, $\$ 404$ (a) (1), 102 Stat. 4642, 4651 (1988), the procedures required under 18 U.S.C. $\$ 3771$ were similar in pertinent part to those set under 28 U.S.C. $\$ 2072$ (1994). 
1958, with the passage of legislation requiring the Judicial Conference of the United States to "carry on a continuous study of the operation and effect" of the Rules, and to recommend from time to time "[s] uch changes in and additions to those rules as the Conference may deem desirable to promote simplicity in procedure, fairness in administration, the just determination of litigation, and the elimination of unjustifiable expense and delay." Pursuant to this mandate, the Judicial Conference authorized the Chief Justice of the United States (in his capacity as Chair of the Conference) to appoint a Standing Committee on Rules of Practice and Procedure, as well as a number of advisory committees to report to the Standing Committee on various fields of procedure. ${ }^{14}$ Under the new procedures set by the Judicial Conference, amendments to the Civil Rules typically moved in turn through the Advisory Committee on Civil Rules, the Standing Committee, the Judicial Conference, and the Supreme Court; if approved by each of these bodies, an amendment would take effect absent legislation to the contrary. ${ }^{15}$

The structure put in place by the Judicial Conference endured in substantially the same form for the next three decades; ${ }^{16}$ but by the

${ }^{19}$ Act of July 18, 1958, Pub. L. No. 85-513, 72 Stat. 356, 356 (codified at 28 U.S.C. $\$ 331(1994)$ ). For a discussion of the Judicial Conference, see infra note 25 and accompanying text.

${ }_{4}$ See Albert B. Maris, Federal Procedural Rule-making: The Program of the Judicial Conference, 47 A.B.A. J. 772, 772 (1961). The members of the Advisory Committees were appointed for overlapping terms of four years, and could (under the initial plan) be reappointed only once. Id. at 774 . Over the years, "the need to retain experienced members and to complete committee projects" would prompt deviations from the oneterm limit on reappointments. WINIFRED R. BROWN, FEDERAL RULEMAKING: ProblemS AND POSSIBILITIES 10 \& n.18 (1981).

${ }^{15}$ See BROWN, supra note 14, at 5-9 (describing the process); Maris, supra note 14, at $775-76$.

${ }^{16}$ After the promulgation of a controversial set of proposed Federal Rules of Evidence in 1972, Congress passed legislation providing that those proposed rules would have no effect unless expressly approved by Congress. See Act of Mar. 30, 1973, Pub. L. No. 93-12, 87 Stat. 9 (providing that the proposed Evidence Rules, and the amendments to the Civil and Criminal Rules promulgated by the Supreme Court in November and December 1972, "shall have no force or effect except to the extent, and with such amendments, as they may be expressly approved by Act of Congress"). Ultimately, Congress enacted the Federal Rules of Evidence in a statute that made substantive changes to some proposed Rules and stylistic changes to others. See Act of Jan. 2, 1975, Pub. L. No. 93-595, 88 Stat. 1926 (1975) (enacting the Federal Rules of Evidence). The resulting legislation altered the enabling statute as well as the proposed rules themselves. In a new enabling provision governing future amendments to the Federal Rules of Evidence, Congress set a 180-day report-and-wait period; purported to empower either house of Congress, acting alone, to block proposed amendments; and provided that any amendment "creating, abolishing, or modifying a privilege shall 
1980 s, the rulemaking process had come under increasing fire. Critics focused variously on a number of perceived problems, including an absence of sufficient public input, ${ }^{17}$ a lack of representativeness on the relevant committees, ${ }^{18}$ a failure by the rulemakers to observe the limits of their power, ${ }^{19}$ the Court's lack of suitability as promulgator of the Rules, ${ }^{20}$ and difficulties with congressional review. ${ }^{21}$ In 1988, Congress responded to these and similar criticisms by amending the Enabling Act. The 1988 amendments, which gave the Act its present structure, ${ }^{22}$ codified the roles of the Standing and Advisory Commit-

have no force or effect unless it shall be approved by act of Congress." Id., 88 Stat. at 1948. (The "one-house veto" provision would be repealed in 1988. See Judicial Improvements and Access to Justice Act, Pub. L. No. 100-702, tit. IV, § 401(c), 102 Stat. 4642, 4650 (1988) (repealing 28 U.S.C. $\$ 2076$ ).)

The 1975 legislation did not modify the Enabling Act as it applied to the promulgation of the Civil Rules, but in the years that followed, Congress would take a more active role in the revision of those Rules as well. See, e.g., Moore, supra note 3, at 1053 (noting "a new willingness on the part of Congress to become involved in the rulemaking process in particular instances").

${ }_{17}^{17}$ Howard Lesnick, The Federal Rule-making Process: A Time for Re-examination, 61 A.B.A. J. 579, 579 (1975).

${ }^{18}$ Id. at 579 .

19 See Burbank, supra note 11, at 1195 (suggesting that "the Judicial Conference should consider the formulation of standards or guidelines delineating the proper spheres of activity of its Rules Committees"); Jack B. Weinstein, Reform of Federal Court Rulemaking Procedures, 76 COLUM. L. REV. 905, 930 (1976) ("Where substantial substantive policies are at stake or fundamental jurisdictional issues are raised, the courts should refrain from treating the matter by rules, but should . . . seek appropriate legislation.").

${ }^{20}$ See Weinstein, supra note 19, at 962 (arguing that members of the Court lack the requisite expertise and time to study the pertinent issues, and that the Court's involvement "inhibits the Court itself and other courts from impartially construing the rules"). Howard Lesnick also noted the "excessive centralization of authority" in the Chief Justice, who appointed the members of the Advisory and Standing Committees, chaired the Judicial Conference, and presided over the Supreme Court deliberations concerning proposed rules. Lesnick, supra note 17 , at 579,581 .

${ }^{21}$ See Lesnick, supra note 17, at 583 (arguing that a "workable mode of genuine congressional review needs to be devised"); Weinstein, supra note 19, at 930 (suggesting guidelines for congressional review of proposed rules to increase "[t]he effectiveness of the rulemaking mechanism under [the] delegation system").

${ }^{22}$ In 1990, Congress added a provision to the Rules Enabling Act authorizing the promulgation of rules to "define when a ruling of a district court is final for the purposes of appeal under [28 U.S.C. § 1291]." Civil Justice Reform Act of 1990, Pub. L. No. 101-650, $\$ 315$, 104 Stat. 5089, 5115 (1990). In 1992, Congress added a provision to 28 U.S.C. $\$ 1292$ authorizing the promulgation, under the Enabling Act, of rules for interlocutory appeals not otherwise provided for in $\$ 1292$. See Federal Courts Administration Act of 1992, Pub. L. No. 102-572, § 101, 106 Stat. 4506, 4506 (1992) (adding new subsection 1292(e) that authorizes the Supreme Court to "prescribe rules, in accordance with [28 U.S.C. \$] $2072 \ldots$, to provide for an appeal of an interlocutory decision to the courts of appeals that is not otherwise provided for under [\$1292] (a), 
tees. Thus, the Enabling Act now requires the Judicial Conference to authorize the appointment of a Standing Committee, and the Act explicitly empowers the Judicial Conference to authorize the appointment of Advisory Committees. ${ }^{23}$

The present statutory structure, then-unlike the original Enabling Act-contemplates that any proposed amendment will be approved by four separate bodies (the Advisory Committee, the Standing Committee, the Judicial Conference, and the Supreme Court) before being reported to Congress. A similar trend is evident in other aspects of the process.

\section{Representation}

As noted above, one criticism of the pre-1988 rulemaking process was that it was unrepresentative. Although the 1988 amendments may not have gone as far as they could have to address this concern, the current statutory framework-in contrast to the original Enabling $\mathrm{Act}^{24}$-does require the involvement of selected practitioners and trial and appellate judges. The Judicial Conference, which since 1958 has been tasked with recommending proposed amendments to the Court, comprises the chief judges of each circuit court of appeals, a district judge chosen by the circuit and district judges of each circuit, and the

(b), (c), or (d)"). Those amendments, however, did not alter the rulemaking structure.

${ }^{23} 28$ U.S.C. $\$ 2073$ (a) (2), (b) (1994). Although a previous proposal would have empowered the Judicial Conference to promulgate the Rules, the 1988 Act leaves that authority with the Supreme Court. H.R. REP. NO. 99-422, at 20 (1985).

${ }^{24}$ As noted above, the Enabling Act of 1934 did not require the Supreme Court to consult any other body prior to submitting proposed Rules to Congress. Although the Court generally delegated the drafting work to the Advisory Committee-thus giving a number of prominent practitioners and academics significant input into the rulemaking process-few lower court judges played a formal role. The Judicial Conference on occasion provided the Court with feedback on rulemaking issues, see, e.g., CHARLES E. Hughes, RePORT OF THE JUdiCIAL CONFERENCE AT WASHINGTON (Sept. 28, 1937) (reporting that the Conference considered the Advisory Committee's proposed draft of the Civil Rules and that "[v]arious questions were raised and discussed, to the end that the Supreme Court should have the advantage of the views of the members of the Conference"), reprinted in 24 A.B.A. J. 75, 78 (1938), but it had no formal role in the process. Instead, the Court communicated directly with the Advisory Committee. See Order on the Appointment of Comm. to Draft Unified Sys. of Equity and Law Rules, 295 U.S. 774, 775 (1935) ("The Advisory Committee shall at all times be directly responsible to the Court."); see also Clark, Federal Rules, supra note 11, at 439-40 (noting that for approximately the first two decades of its existence, the Advisory Committee's office was located in the Supreme Court's own building). 
chief judge of the Court of International Trade. ${ }^{25}$ In 1988, moreover, Congress-seeking to "provide[] for greater participation by all segments of the bench and bar" ${ }^{26}$-specified that any Advisory Committees created under the Enabling Act "shall consist of members of the bench and the professional bar, and trial and appellate judges." ${ }^{27} \mathrm{Al}-$ though the Enabling Act does not require the creation of Advisory Committees, in practice there has long been an Advisory Committee on Civil Rules, and the Act's directive concerning Advisory Committee composition thus ensures that at least some practitioners, as well as a number of judges, will be involved in the rulemaking process. Moreover, the public notice-and-comment period-which is discussed below-provides an additional opportunity for practitioners and other members of the public to voice their views of a proposed amendment.

\section{Public Access and Input}

The 1988 Act responded to a perception of "a lack of openness, and, in part as a consequence, the perception of overreaching by the rulemakers"; ${ }^{28}$ accordingly, the Enabling Act, as amended in 1988, includes a number of provisions designed to further a notice-andcomment rulemaking process. $^{29}$

The drafters of the 1988 legislation-seeking to "parallel the openness requirements of the House and Senate committees and subcommittees"-made the rulemakers' activities more accessible to the public. $^{30}$ The Judicial Conference must publish its procedures for the consideration of proposed amendments." The meetings of the Advisory and Standing Committees are (with limited exceptions) open to the public, and sufficient notice must be given of each meeting to en-

${ }^{25} 28$ U.S.C. $\$ 331$ (1994). The district judges serve for terms of three to five years. Id. The membership of the Judicial Conference in 1958 was similar, except that it included the chief judge of the Court of Claims rather than the chief judge of the Court of International Trade. Maris, supra note 14, at 774.

${ }^{26}$ H.R. REP. NO. 99-422, at 4.

${ }^{27}$ Pub. L. No. 100-702, tit. IV, § 401, 102 Stat. 4642, 4649 (codified at 28 U.S.C. $\S 2073(\mathrm{a})(2)(1994))$.

${ }^{28}$ H.R. REP. NO. 99-422, at 16; see also H.R. REP. NO. 100-889, at 26 (1988) (noting that H.R. REP. NO. 99-422 "applies to the provisions of title I [concerning the Rules Enabling Act], except as noted below").

${ }^{29}$ A number of these measures had already been implemented, to varying degrees, in the procedures published by the Judicial Conference in 1983. 98 F.R.D. 389 (1983).

${ }^{30}$ H.R. REP. NO. 99-422, at 25.

3128 U.S.C. $\$ 2073$ (a) (1) (1994). 
able interested persons to attend. ${ }^{32}$ Minutes of the meetings must (again with limited exceptions) be made available to the public. ${ }^{33}$ And in making recommendations, the Advisory Committee and Standing Committee must "provide a proposed rule, an explanatory note on the rule, and a written report explaining the body's action, including any minority or other separate views." ${ }^{\mathbf{9 4}}$

Similarly, the process is designed to make the public aware of proposed amendments. Proposals are circulated to the public for comment, and currently " $[\mathrm{m}]$ ore than 10,000 persons and organizations are on the mailing list." ${ }^{35}$ Interested persons may submit written suggestions and may testify at public hearings on the proposals. ${ }^{36}$ "[T]o the extent feasible," the rulemakers acknowledge all written suggestions and advise each person who makes a suggestion of the Advisory Committee's action thereon. ${ }^{37}$ Admittedly, noncontroversial proposals often attract little attention from practitioners or other members of the public. More contested issues, however, have drawn a wide range of input. The Advisory Committee's 1990 call for comments on Rule 11, for example, elicited written responses from "[w] ell

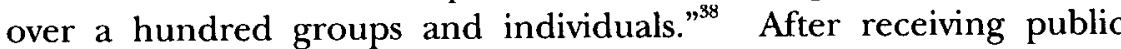
comments on its proposed amendments to the Rule, the Advisory Committee responded by making a number of changes to both the

3228 U.S.C. $\$ 2073$ (c) (1)-(2); see H.R. REP. NO. 99-422, at 25 (“[T] here is a strong presumption that when conducting the quasi-legislative activities authorized by this act that such meetings occur in the open.").

39 28 U.S.C. $\$ 2073$ (c) (1) (1994).

${ }^{94} 28$ U.S.C. $\$ 2073(\mathrm{~d})(1994)$.

35 Leonidas Ralph Mecham, Federal Rulemaking: The Rulemaking Process-A Summary for the Bench and Bar, at http://www.uscourts.gov/rules/proceduresum.htm (last visited Jan. 11, 2002).

Id.

${ }^{37}$ Procedures for the Conduct of Business by the Judicial Conference Committees on Rules of Practice and Procedure [hereinafter Judicial Conference Procedures], reprinted in 195 F.R.D. $386,386-87$ (2000). Although this is not a statutory requirement, the Judicial Conference rules in effect during the drafting and consideration of the 1988 amendments included a similar provision, see Rules Enabling Act of 1985: Hearing Before the Subcomm. on Courts, Civil Liberties, and the Admin. of Justice of the H. Comm. on the Judiciary on H.R. 2633 and H.R. 3550, 99th Cong. 85, 87 (1985) [hereinafter Hearing] (reprinting Standing Committee procedures), and this requirement was noted in the House report on the bill that would form the basis of the amendments, see H.R. REP. NO. 99-422, at 10.

${ }^{38}$ AdDISORY COMM. ON CIVIL RULES, COMM. ON RULES OF PRACTICE AND PROCEDURE OF THE JUDICIAL CONFERENCE OF THE U.S., INTERIM REPORT ON RULE 11, at 1 [hereinafter INTERIM REPORT], reprinted in GEORGENE M. VAIRO, RULE 11 Sanctions: Case Law Perspectives and Preventive Measures, app. I, at I-3 (2d ed. 1991). 
text and the Notes. ${ }^{39}$

\section{E. The Advisory Committee Notes}

From the outset, the Advisory Committee followed a practice of providing an explanatory Note when it forwarded a proposed new Rule or amendment for approval. Over the years, the Notes have increased in significance, and they now play an integral role in the rulemaking process.

The Advisory Committee Notes that accompanied the original Rules were often terse, and the Advisory Committee itself apparently did not intend that they be given binding effect. ${ }^{40}$ The length of the Notes increased markedly by the 1960s, however, and the Notes now contain a significant amount of explanatory information. A survey of Notes to amendments promulgated since 1988 shows that the Advisory Committee currently uses the Notes to indicate an amendment's purpose, ${ }^{41}$ guide future interpretations, ${ }^{42}$ discuss the amendment's rela-

${ }^{39}$ See Letter from Sam C. Pointer, Jr., Chairman, Advisory Committee on Civil Rules, to Robert E. Keeton, Chairman, Standing Committee on Rules of Practice and Procedure, attachment B (May 1, 1992), reprinted in 146 F.R.D. 519, 523-25 (1993) (noting a number of criticisms made during the public comment period and detailing some changes Advisory Committee had made, in response, to the text and Notes of the proposed amendments).

40 As the Advisory Committee's introductory statement put it, "The notes are not part of the rules, and the Supreme Court has not approved or otherwise assumed responsibility for them. They have no official sanction, and can have no controlling weight with the courts, when applying the rules in litigated cases." Henry P. Chandler, Some Major Advances in the Federal Judicial System, 1922-1947, 31 F.R.D. 307, 503 (1963) (quoting 3A William W. Barron \& Alexander Holtzoff, Federal Practice aNd PROCEDURE (1958) (quoting the introductory statement)).

${ }^{41}$ See, e.g., FED. R. CIV. P. 4 advisory committee's note (1993) ("The general purpose of this revision is to facilitate the service of the summons and complaint."); FED. R. CIV. P. 26 advisory committee's note (1993) ("A major purpose of the revision [to Rule 26(a)] is to accelerate the exchange of basic information about the case ...."); $i d .2000$ advisory committee's note (stating that the amendments "restore national uniformity to disclosure practice [and] to other aspects of discovery"); FED. R. CIV. P. 30 advisory committee's note (1993) (explaining that the aims of new Rule 30(a) (2) (A) are to assure judicial review before any side takes more than ten depositions without consent of other parties and "to emphasize that counsel have a professional obligation to develop a mutual cost-effective plan for discovery"); FED. R. CIV. P. 33 advisory committee's note (1993) ("The purpose of this revision is to reduce the frequency and increase the efficiency of interrogatory practice."); FED. R. CIV. P. 45 advisory committee's note (1991) (listing five purposes for the amendment); FED. R. CrV. P. 53 advisory committee's note (1991) ("The purpose of the revision is to expedite proceedings before a master."); FED. R. CIV. P. 77 advisory committee's note (1991) ("The purpose of the revisions is to permit district courts to ease strict sanctions now imposed on appellants whose notices of appeal are filed late because of their failure to receive notice of 


\section{F. The Report-and-Wait Requirement}

The final significant aspect of the rulemaking process, for present purposes, is the requirement that each proposed amendment be reported to Congress, so that Congress has an opportunity to enact legislation preventing the amendment from taking effect. The reportand-wait period-which since 1950 had been only ninety days for the Civil Rules-more than doubled in 1988, so that Congress now has at least seven months in which to review proposed amendments. ${ }^{54}$ It is evident from past experience that proposed amendments may nonetheless survive the waiting period, despite substantial congressional opposition; but the report-and-wait feature is important because it requires that both the text of a proposed Rule and its Note be set before Congress prior to taking effect.

Admittedly, Congress has interfered only sporadically in the rulemaking process, ${ }^{55}$ and congressional inertia has foiled several attempts

member of the Advisory Committee on Civil Rules, the members and Reporters-as well as members of the public commenting on possible changes-devoted considerable attention to the explanatory notes as well as to the text of proposed rules.").

${ }^{54}$ The statute provides that:

The Supreme Court shall transmit to the Congress not later than May 1 of the year in which a rule prescribed under section 2072 is to become effective a copy of the proposed rule. Such rule shall take effect no earlier than December 1 of the year in which such rule is so transmitted unless otherwise provided by law.

28 U.S.C. $\$ 2074$ (a) (1994).

${ }^{55}$ The most dramatic congressional intervention came in the early $1970 \mathrm{~s}$, in response to the proposed Rules of Evidence. Critics of the proposed evidence rules argued that some of the rules were outside the scope of the Enabling Act delegation, and that other rules were ill-advised as a policy matter. The debate convinced Congress that it "could not properly dispose of the matter before the July 1, 1973 deadline," 120 CONG. REC. H40,890 (daily ed. Dec. 18, 1974) (statement of Rep. Hungate), and in March 1973 a law was passed providing that the rules had "no force or effect except to the extent, and with such amendments, as they may be expressly approved by Act of Congress." Act of Mar. 30, 1973, Pub. L. No. 93-12, 87 Stat. 9. Ultimately-more than a year and a half later-the Federal Rules of Evidence were enacted by Congress, in a statute that made substantive changes to some proposed Rules and stylistic changes to others. See Act of Jan. 2, 1975, Pub. L. No. 93-595, 88 Stat. 1926 (1975) (enacting Federal Rules of Evidence). Subsequently, "Congress went on to examine at length, and make major and detailed revisions in, criminal rules submitted in 1974 and habeas corpus amendments submitted in 1976." BROWN, supra note 14, at 3; see also id. at 33 \& n.76 (stating that "Congress may defer all or part of the promulgated rules, and after deferral, it may approve, amend, or reject them," and describing congressional action after deferral of two sets of rules in the 1970s). Similarly, in 1982 Congress delayed the effective date of proposed amendments to Rule 4, see Act of Aug. 2, 1982, Pub. L. No. 97-227, 96 Stat. 246, and ultimately made a number of adjustments to the amendments before enacting them by legislation, see Act of Jan. 12, 1983, Pub. L. No. 97-462, 96 Stat. 2527 (enacting amendments to Rule 4); see also 4 CHARLES ALAN WRIGHT \& ARTHUR R. 
to delay or alter proposed Rules. For example, though the initial set of Rules prompted hearings in both houses of Congress and aroused significant resistance in the Senate, no legislation resulted. ${ }^{56}$ A commentator surmised that

[p] erhaps one of the reasons that the opponents of the rules in the Senate did not press the issue to a vote was that concurrent action of both houses of Congress would have been necessary to prevent them from becoming effective. Delaying action of the Senate only would have been futile. There was no prospect of such action in the House of Representatives.

Miller, Federal Practice \& Procedure $\$ 1001$, at 8-9 (3d ed. 2002) (discussing the 1983 amendments to Rule 4); David D. Siegel, Practice Commentary on Amendment of Federal Rule 4 (eff. Feb. 26, 1983) with Special Statute of Limitations Precautions, 96 F.R.D. 88, 94-97 (discussing the 1983 amendments to Rule 4 and noting instances where the amendments as enacted by Congress differed from the amendments as promulgated by the Supreme Court).

At other times, the passage of legislation on a substantive topic has led Congress to modify the rules of procedure as well. Thus, the Private Securities Litigation Reform Act of 1995 altered the application of Rule 11 in certain securities cases, see 15 U.S.C. \$ 77z-1 (c) (Supp. II 1996) (directing the court, at the conclusion of private action under the Securities Act of 1933 , to make certain findings concerning compliance with Rule 11 (b); in the event that those findings disclose a violation of Rule 11 (b), removing court's discretion not to impose sanctions for the violation; and creating a presumption that the appropriate sanction for substantial failure of complaint to comply with Rule 11 (b) is an award to defendant of the reasonable attorneys' fees and expenses incurred in the action); id. $\$ 78 \mathrm{u}-4$ (c) (Supp. II 1996) (imposing similar requirements in private actions under the Securities Exchange Act of 1934), heightened the pleading requirements in securities fraud cases, see id. $\$ 78 u-4$ (b) (Supp. II 1996) (requiring, inter alia, that the complaint "state with particularity facts giving rise to a strong inference that the defendant acted with the required state of mind"), required special certifications by proposed representatives of plaintiff classes, see id. $\$ 77 \mathrm{z}-1$ (a) (2) (A) (Supp. II 1996) (imposing certification requirement in class actions under Securities Act of 1933); id. $\$ 78 \mathrm{u}-4$ (a)(2)(A) (Supp. II 1996) (imposing certification requirement in class actions under the Securities Exchange Act of 1934), and provided for the appointment of a lead plaintiff, see id. $\$ 77 \mathrm{z}-1$ (a) (3) (Supp. II 1996) (providing for appointment of lead plaintiff in class actions under the Securities Act of 1933); $\mathrm{id}$. $\$ 78 \mathrm{u}-$ 4(a) (3) (Supp. II 1996) (providing for appointment of a lead plaintiff in class actions under the Securities Exchange Act of 1934).

On occasion, Congress has amended a Rule in order to conform it to newly enacted legislation. See, e.g., Equal Access to Justice Act, Pub. L. No. 96-481, § 205, 94 Stat. 2325, 2330 (1980) (repealing FED. R. CIV. P. 37(f)).

See Chandler, supra note 40, at 506-12 (describing reactions to the initial set of Rules in the House and Senate).

${ }^{57}$ Id. at 511; see also Friedenthal, supra note 11, at 674 (finding it "doubtful that these alterations in federal procedure could have been made by Congress in the face of opposition from trial attorneys"). Although the vote to which Chandler referred concerned a resolution to postpone the Rules' effective date, rather than to disapprove them outright, the postponement effort apparently was spearheaded by opponents of the Rules as promulgated. See Chandler, supra note 40, at 509 (describing Senator Wil- 
tion to surrounding law, ${ }^{43}$ and provide practice tips for lawyers and judges. $^{44}$ Of particular significance to the present discussion, the Notes are designed to inform the rulemaking process itself. ${ }^{45}$

The Enabling Act, as amended in 1988, requires each body that proposes or forwards an amendment to include an "explanatory note" with each proposed Rule. ${ }^{46}$ Thus, the Advisory Committee Reporter's first draft of a proposed amendment includes " Committee Notes' explaining [the amendment's] purpose and intent." ${ }^{47}$ After the Advisory Committee meets to consider and revise "the draft proposed new rules and rules amendments, together with Committee Notes,"

entry of a judgment.").

${ }^{42}$ See, e.g., FED. R. CIV. P. 50 advisory committee's note (1991) ("Paragraph (a) (1) articulates the standard for the granting of a motion for judgment as a matter of law. It effects no change in the existing standard."); FED. R. CIV. P. 50 advisory committee's note (1993) (reaffirming that "the 1991 revision ... was not intended to change the existing standards under which 'directed verdicts' could be granted").

${ }^{43}$ See, e.g., FED. R. CrV. P. 11 advisory committee's note (1993) (discussing the Rule's relationship to courts' inherent powers); FED. R. CIV. P. 16 advisory committee's note (1993) (same); FED. R. CIV. P. 37 advisory committee's note (2000) (same).

${ }^{44}$ See, e.g., FED. R. CIV. P. 4 advisory committee's note (1993) ("If electronic means such as facsimile transmission are employed [in sending the notice and request for waiver of service of summons under Rule 4(d)], the sender should maintain a record of the transmission to assure proof of transmission if receipt is denied ...."); FED. R. CIV. P. 30 advisory committee's note (2000) (suggesting a variety of factors parties and courts should take into account when considering extending the time for a deposition); FED. R. CIV. P. 37 advisory committee's note (1993) ("If the party required to make the disclosure would need the material to support its own contentions, the more effective enforcement of the disclosure requirement will be to exclude the evidence not disclosed ...."); FED. R. CIV. P. 43 advisory committee's note (1996) ("The most persuasive showings of good cause and compelling circumstances are likely to arise when a witness is unable to attend trial for unexpected reasons, such as accident or illness, but remains able to testify from a different place."); FED. R. CIV. P. 48 advisory committee's note (1991) ("[T] he parties should not other than in exceptional circumstances be encouraged to waive the right to a jury of six, not only because of the constitutional stature of the right, but also because smaller juries are more erratic and less effective in serving to distribute responsibility for the exercise of judicial power."); FED. R. CIV. P. 83 advisory committee's note (1995) ("Furnishing litigants with a copy outlining the judge's practices-or attaching instructions to a notice setting a case for conference or trial-would suffice to give actual notice ....").

${ }^{45}$ One Note includes a comment designed specifically to flag issues for consideration during the rulemaking process itself. See FED. R. CIV. P. 4 advisory committee's note (1993) ("Mindful of the constraints of the Rules Enabling Act, the Committee calls the attention of the Supreme Court and Congress to new subdivision (k)(2)."), reprinted in 146 F.R.D. 557, 557-58 (1993). More generally, the Notes provide guidance to participants in the rulemaking process, as well as to subsequent interpreters.

${ }^{46} 28$ U.S.C. $\$ 2073$ (d) (1994).

${ }^{4}$ Judicial Conference Procedures, supra note 37, at 387.

${ }^{48}$ Id:; see also, e.g., Civil Rules Advisory Committee, Draft Minutes, Apr. 23-24, 
and Notes are submitted for approval of publication; ${ }^{49}$ and the proposals circulated for public comment accordingly include Notes as well as text. Likewise, when the Advisory Committee meets to decide whether to submit the proposed Rules and their Notes to the Standing Committee for adoption, ${ }^{50}$ it considers, and may revise, both text and Notes. ${ }^{51}$ The Standing Committee, similarly, may change the relevant Note before approving a proposed Rule and forwarding it to the Judicial Conference. ${ }^{52}$ The Notes, as well as the text, of proposed Rules amendments are forwarded to the Judicial Conference and, in turn, to the Supreme Court and then to Congress.

Thus, the Enabling Act now requires that each proposed amendment be accompanied-throughout the approval process-by an Advisory Committee Note; and these Notes are drafted, redrafted, voted on, and approved in much the same manner as the text of the proposed Rules.

2001, at 43 [hereinafter Draft Minutes] (noting Advisory Committee decision to add language to Note accompanying proposed Rule 53, and stating that "[w]ith this change in the Note, subdivision [53] (i) was approved").

${ }_{50}^{4}$ Judicial Conference Procedures, supra note 37 , at 387-88.

See id. at 389-90 ("The Advisory Committee shall submit proposed rules changes and Committee notes, as finally agreed upon, to the Standing Committee.").

${ }^{51}$ See, e.g., Draft Minutes, supra note 48, at 6 ("It was agreed that a reminder of this requirement should be added to the Committee Note.... With this addition, Rule 58(a) (1) was approved for submission to the Standing Committee for adoption.").

${ }_{52}$ The 1980 amendments to Rule 37 provide an illustration. The Advisory Committee's proposed amendments to Rule 37 included the addition of a new subsection (h) that would have permitted the district court, when appropriate, to "notify the Attorney General of the United States and other appropriate heads of offices or agencies thereof in writing, that the United States, through its officers or attorneys, has failed to participate in good faith in discovery." STANDING COMM. ON RULES OF PRACTICE AND PROCEDURE, EXCERPT From THE REPORT TO THE CHIEF JUSTICE OF THE UNITED States, Chairman, and The Members of The Judicial Conference of the UNited STATES, in 85 F.R.D. 536, 536 (1980) (quoting Advisory Committee proposal). Based on its belief that district courts "already ha[d]" such authority, the Standing Committee rejected the proposed Rule $37(\mathrm{~h})$. Id. at 537. Instead, "with the concurrence" of the Chair of the Advisory Committee, the Standing Committee added a paragraph to the Notes noting such authority. Id.

Admittedly, changes made by the Standing Committee may be problematic if the Committee fails to make all the revisions necessary to conform the Note to the revised proposal. For example, Stephen Burbank has noted that when the Standing Committee recommended in the fall of 1992 that the Judicial Conference approve an alternative version of a proposed amendment to Rule 4, "the rulemakers failed to clean up" a relevant paragraph of the Note to reflect the changes made by the Standing Committee. Stephen B. Burbank, The Reluctant Partner: Making Procedural Law for International Civil Litigation, 57 LAW \& CONTEMP. ProBS., Summer 1994, at 103, 117 n.120.

${ }_{53}$ See Thomas D. Rowe, Jr., A Square Peg in a Round Hole? The 2000 Limitation on the Scope of Federal Civil Discovery, 69 TENN. L. REV. 13, 29 (2001) ("In my experience as a 
Similarly, the 1983 amendments to Rule 11 took effect-despite congressional opposition-on August 1, 1983. On July 26, the House had passed a bill that would have deferred the effective date for four months. ${ }^{58}$ However, when the bill was transmitted to the Senate, that body unanimously ordered it "held at the desk until the close of business" on July $29^{59}$ As the Reporter to the Advisory Committee later recalled, "[i]t was one of those death-defying cliff-hangers because a bill to delay [the amendments'] effectiveness was sitting in the well of the Senate on the appropriate morning, but no one hauled it out." Instead, on Friday, July 29, the Senate referred the bill to the Judiciary Committee $^{61}$ - which, as the amendments were to take effect the following Monday, "doomed the effort to delay the effective date." 62 Accordingly, the amendments "by the thinnest hair you can think of became effective on August 1, 1983."63 The 1993 amendments to Rules 11 and 26, likewise, sparked debate in Congress, but Congress again failed to act. After subcommittees of the House and Senate Judiciary Committees held hearings on the proposed amendments in June and July 1993, respectively, ${ }^{64}$ bills were introduced in both houses to delay

liam H. King's introduction of a joint resolution delaying the effective date of the Rules and predicting numerous questions concerning the extent to which the Rules would conflict with and supersede existing federal law); id. at 511 (stating that “[b]esides Senator King, a number of Senators, including leaders like Connally of Texas, Minton of Indiana, and Norris of Nebraska viewed the rules with disfavor").

${ }^{58}$ See 129 CoNG. REC. 20,857 (1983) (statement of Rep. Rodino) (explaining that the bill would defer the effective date of the amendments until December 1 "so as to provide Congress with the time it needs to examine these proposals"); id. at 20,859 (noting that the bill was passed by the House).

59129 CONG. REC. 20,818 (1983). The record actually states that the bill was to be "held at the desk until the close of business on Monday July 29, 1983," id., leaving an ambiguity as to whether the intended date was Friday, July 29, or Monday, August 1; in any event, as noted below, the Senate referred the bill to the Judiciary Committee on the 29 th.

${ }^{60}$ ARTHuR R. MILleR, THE August 1983 AmendMENTS TO THE Federal Rules of Civil Procedure: Promoting effective Case Management and LaWyer RESPONSIBILITY 1 (1984), quoted in Stephen B. Burbank, The Transformation of American Civil Procedure: The Example of Rule 11, 137 U. PA. L. REV. 1925, 1948 n.119 (1989).

${ }^{61}$ See 129 CONG. REC. 21,618 (1983) ("The following bill ... w[as] read the first and second times by unanimous consent, and referred as indicated: H.R. 3497. A bill to defer proposed amendments to the Federal Rules of Civil Procedure ...; to the Committee on the Judiciary.").

${ }^{62}$ Burbank, supra note 60 , at 1948 n.119.

${ }^{63}$ MiLLER, supra note 60, at 1, quoted in Burbank, supra note 60, at 1948 n.119.

${ }^{64}$ See 139 CONG. REC. D664, D666 (daily ed. June 16, 1993) (noting that the House Subcommittee on Intellectual Property and Judicial Administration held oversight hearing on amendments to the Federal Rules); 139 CONG. REC. D860, D863 (daily ed. July 28, 1993) (noting that the Senate Subcommittee on Courts and Admin- 
the effective date of the proposed amendments to Rule $11 .^{65}$ The bills were referred to the House and Senate Judiciary Committees, ${ }^{66}$ and never reached the floor of either house. The House did pass a separate bill to delete certain controversial amendments to the discovery rules, ${ }^{67}$ but that bill, too, never reached the Senate floor, ${ }^{68}$ and accordingly the amendments took effect. ${ }^{69}$

As these events illustrate, amendments sometimes may survive congressional review for reasons unrelated to their merits. Congress might be busy with more urgent matters, it might be unable to reach consensus, or it might simply run out of time. On the other hand, it is also possible that some amendments fail to provoke contrary legislation because-even if some legislators oppose the amendments-a

istrative Practice held hearings on proposed amendments to Federal Rules as well as other matters). During the House subcommittee hearing, "[c]onsiderable attention was given to the proposed Rule 11 changes.” H.R. REP. NO. 103-319 (1993).

${ }^{65}$ See 139 CoNG. REC. H6377, H6380 (daily ed. Aug. 6, 1993) (H.R. 2979); 139 CONG. REC. S10565, at S10566 (daily ed. Aug. 5, 1993) (S. 1382).

139 CONG. REC. H6377, H6380 (daily ed. Aug. 6, 1993); 139 Cong. REC. S10,565, at S10566 (daily ed. Aug. 5, 1993).

See 139 CONG. REC. H8744, H8745, H8747 (daily ed. Nov. 3, 1993) (noting passage by the House of H.R. 2814, which would strike proposed Rule 26(a) (1)-concerning initial disclosures-and make other changes to proposed Rules 26 and 30).

${ }^{68}$ Representative Hughes, the co-sponsor of the House bill concerning the discovery rules, described the bill's fate in the Senate as follows:

Subsequent to the House passage of H.R. 2814 on November 3, 1993, the Senate informally began to consider the House-passed bill under a procedure which placed it directly on the Senate calendar without further Senate Judiciary Committee action.

Reportedly, plaintiffs and civil rights organizations began at this late date to encourage the Senate to amend H.R. 2814 by adding a provision that would cancel the presumptive limits on depositions and interrogatories in the proposed rules.

As the first session of the Congress came close to its conclusion, attempts to negotiate a compromise failed. This even included a proposal to defer several of the controversial rules for six months.

On one hand certain Senators wanted to expand or abolish the presumptive limits. Others wanted a vote on Senator Brown's amendment to delay the implementation of Rule 11 changes for a year. The plaintiffs' bar and civil rights groups were adamantly opposed to delaying the Rule 11 changes.

William J. Hughes, Congressional Reaction to the 1993 Amendments to the Federal Rules of Civil Procedure, 18 SETON HALl LEGIS. J. 1, 10-11 (1993) (citations omitted).

69) See Michael J. Wagner, Too Much, Too Costly, Too Soon? The Automatic Disclosure Amendments to Federal Rule of Civil Procedure 26, 29 TORT \& INS. L.J. 468, 470 (1994) ("With the Senators unable to reach an agreement on the amendments, the bill was not cleared for floor action, and the amended rules went into effect by default on December 1. Both lawyers and judges were surprised that the amendments became law through congressional inaction."). 
sufficient number find the proposals unobjectionable. In such instances, the legislators who vote against the blocking legislation may do so based on their understanding of the pertinent Advisory Committee Note, as well as the proposed Rule's text. As required by the Enabling Act, text and Notes are transmitted to Congress together, and a legislator (or congressional aide) seeking to understand an amendment's effect may well read-and rely on-both. Since 1934, then, the rulemaking structure has evolved to include more decision makers, to provide for the representation of persons other than the Justices of the Supreme Court, to facilitate public notice and comment, to provide Notes that accompany the text throughout the drafting and approval process, and to lengthen the opportunity for congressional review. None of these changes came about as a matter of grace on the part of the Supreme Court; rather, they were imposed by Congress through changes to the enabling legislation. In the Parts that follow, I argue that these statutory requirements, and the practices under them, have significant implications for the interpretation of the Rules.

\section{DELEGATION AND DISCRETION}

As noted above, prior commentators have posited that the Enabling Act increases the Supreme Court's interpretive discretion "because the Court is promulgator as well as interpreter" of the Rules. Judge Moore, for example, contends that "[g]iven [the] substantial, although largely unexercised, powers of the Court in the promulgation process, a more activist role in the interpretative stage, one that considers purpose and policy, is appropriate." As Part III will discuss, some lower courts have similarly felt free to strain the Rules' text, and ignore relevant Notes, in order to implement their own views of desirable policy. I argue that such an approach enlarges the powers of the

${ }^{70}$ Moore, supra note 3, at 1095. Aside from the other difficulties with this view, it fails to take account of the fact that the Court that interprets a given Rule will not necessarily be the same Court that promulgated it.

7) Moore, supra note 3, at 1093. Similarly, Bauer argues that:

In construing the Federal Rules, the courts are interpreting standards which the Supreme Court itself has promulgated. Therefore, some of the problems which occur during statutory interpretation, such as ferreting out legislative intent, deferring to another branch of the government, or avoiding violations of principles of federalism by deferring to state interests, are in large measure eliminated.

Bauer, supra note 3, at 720. 
courts beyond their proper boundaries. ${ }^{72}$ The structure of the Enabling Act delegation and the reality of the rulemaking process together suggest that courts should have, if anything, less latitude to interpret the Rules than they do to interpret statutes. This Part explains why the principles to be drawn from the Enabling Act's structure and function foreclose Moore's argument. The issue, however, cannot be settled by abstract principles alone. Rather, to see the practical implications of Moore's approach, it is necessary to examine a concrete case in some detail. To define the terms of the argument, I first take, as an example, the Supreme Court's interpretation of Rule 11 in Pavelic $\mathcal{E}$ LeFlore v. Marvel Entertainment Group. ${ }^{73}$

Rule 11, as amended in 1983, required that every litigation paper filed on behalf of a represented party "be signed by at least one attorney of record in his individual name"; similarly, pro se litigants were required to sign their litigation papers. ${ }^{74}$ The Rule further provided:

The signature of an attorney or party constitutes a certificate by the signer that he has read the pleading, motion, or other paper; that to the best of his knowledge, information, and belief formed after reasonable inquiry it is well grounded in fact and is warranted by existing law or a good faith argument for the extension, modification, or reversal of existing law, and that it is not interposed for any improper purpose, such as to harass or to cause unnecessary delay or needless increase in the cost of litigation. ${ }^{75}$

${ }^{72}$ Much of the argument that follows focuses on the Supreme Court rather than on lower federal courts. In part, this is because a number of Judge Moore's arguments relate to the Supreme Court in particular. (For instance, Moore's contention that the Rules Enabling Act delegation provides a license for dynamic interpretation of the Rules applies most strongly to the Supreme Court, since that Court is the body authorized to transmit proposed rules to Congress.) Likewise, some parts of my analysis focus specifically on the Supreme Court. See infra text accompanying notes 112-121 (discussing the role of the Supreme Court in the rulemaking process); infra text accompanying notes 152-155 (same); see also infra Part II.C (discussing potential disadvantages of policymaking by the Supreme Court). Other parts of my argument, however, apply with equal force to interpretation by lower federal courts, see, e.g., infra text accompanying notes 145-150 (discussing the inapplicability of the statutory obsolescence argument to the rulemaking context), and I contend that lower courts also should adopt my suggested interpretive approach. Accordingly, I illustrate my discussion in Part III by describing the consequences that attended the Seventh Circuit's use of a contrary method. See infra text accompanying notes 180-210 (discussing the Seventh Circuit's disregard of Rule 11's text and Note).

493 U.S. 120 (1989).

${ }^{74}$ FED. R. CrV. P. 11 (1983). In 1987, Rule 11 was amended to make its language gender neutral. 113 F.R.D. 189, 280-81 (1987). This alteration did not, however, affect the questions at issue in Pavelic.

${ }^{75}$ FED. R. CIV. P. 11 (1983). 
For violations of this certification provision, the Rule dictated that the court "shall impose upon the person who signed [the paper], a represented party, or both, an appropriate sanction."

Although the text of the 1983 Rule thus appeared to authorize sanctions only against the signing attorney or the client, two lower courts held in Pavelic that the Rule also authorized sanctions against the offending attorney's law firm. ${ }^{77}$ The attorney in question had signed his court papers:

\section{Pavelic \& LeFlore}

By /s/ Ray L. LeFlore

(A Member of the Firm)

Attorneys for Plaintiff ${ }^{38}$

The district court, reasoning that " $[\mathrm{t}]$ he law firm is the attorney of record, and it is the law firm on whose behalf the papers are signed," imposed a $\$ 50,000$ sanction on the attorney and his firm, jointly and severally. ${ }^{79}$ In the district court's view, "[o]nly if the partnership as a whole is held responsible for the acts of its attorneys will the potential of the rule in curbing abuses be fully recognized." cuit agreed, holding that the deterrent purposes of the 1983 amendments were best served by a presumption that the law firm, as well as the individual attorney, should be subject to sanctions. ${ }^{81}$ One commentator, citing the "school of thought that says the court has much greater latitude in interpreting its own rules, even though it delegates the drafting work to advisory committees," predicted that the Court would likewise resolve the issue based on policy considerations. ${ }^{82}$

When the Supreme Court reversed, however, the core of its argument was that the Rule's text provided no authority for courts to sanction law firms and that the Court's "task is to apply the text, not to improve upon it." ${ }^{83}$ Justice Scalia, writing for the majority, conceded that

${ }^{70} I d$.

77 Pavelic, 493 U.S. at 122.

${ }^{78} I d$.

${ }^{79}$ Calloway v. Marvel Entm't Group, 650 F. Supp. 684, 686, 688 (S.D.N.Y. 1986), aff'd in part and rev'd in part, 854 F.2d 1452 (2d Cir. 1988), rev'd in part sub nom. Pavelic \& LeFlore v. Marvel Entm't Group, 493 U.S. 120 (1989).

${ }^{80}$ Id. at 687 .

${ }^{81}$ Calloway v. Marvel Entm't Group, 854 F.2d 1452, 1479-80 (2d Cir. 1988), rev'd in part sub nom. Pavelic \& LeFlore v. Marvel Entm't Group, 493 U.S. 120 (1989).

${ }^{82}$ Marcia Coyle, Supreme Court Ponders Sanctions: Rule 11: Guilt by Partnership?, NAT'L L.J., Oct. 9, 1989, at 3 (quoting Gregory P. Joseph).

${ }^{83}$ Pavelic, 493 U.S. at 126. 
"viewed in isolation, the phrase 'person who signed' is ambiguous," but maintained that Rule 11, read as a whole, settled the question: "[I]n a paragraph beginning with a requirement of individual signature, and then proceeding to discuss the import and consequences of signature, we think references to the signer in the later portions must reasonably be thought to connote the individual signer mentioned at the outset." ${ }^{85}$ The Court placed weight on the Rule's requirement that documents be signed "in the attorney's individual name": "Where the text establishes a duty that cannot be delegated [i.e., certification through signature], one may reasonably expect it to authorize punishment only of the party upon whom the duty is placed." ${ }^{86}$ Finally, the Court rejected the lower courts' policy-based arguments, reasoning that "holding a law firm accountable for its attorney's violation" would not necessarily further the Rule's aim of "bring[ing] home to the individual signer his personal, nondelegable responsibility."

Pavelic is a good example of the importance of adhering to the text and Notes of a Rule. Read together, the Rule's three references to signature (with respect to the requirement of signing, the significance of signing, and the sanctions for violations of the signing requirement) indicate that the Rule contemplated sanctions only against parties and signing attorneys, not law firms. Moreover, the accompanying Note discussed the signing attorney's liability without giving any suggestion that the Rule was thought to extend to the signer's firm. ${ }^{88}$ Indeed, had the 1983 amendments authorized sanctions against law firms, such a feature would have merited scrutiny during the rulemaking process. In Pavelic itself, the target of the court's $\$ 50,000$ sanction was a two-man firm, which included the signer of the papers and a partner who appears to have been mainly a transactional lawyer. ${ }^{89}$ Although Pavelic, the transactional partner, observed several

${ }^{84} I d$. at 123 .

${ }^{85}$ Id. at 124 .

${ }^{86}$ Id. at 125 .

${ }^{87}$ Id. at 126. In dissent, Justice Marshall offered a purposive interpretation similar to those relied upon by the lower courts; he argued that "[o]ne of the fundamental purposes of Rule 11 is to strengthen the hand of the trial judge in his efforts to police abusive litigation practices." Id. at 127 (Marshall, J., dissenting).

${ }^{88}$ Thus, for example, the Note emphasized that the 1983 amendments placed responsibility on "anyone who signs a pleading, motion, or other paper" and explained that the amendments were designed to make clear the court's discretion "to impose sanctions on either the attorney, the party the signing attorney represents, or both." FED. R. CIV, P. 11 advisory committee's note (1983).

${ }^{89}$ Pavelic's practice area is currently listed in the West Legal Directory database as "Estate Planning." 
days of depositions and trial in the case and was active in retaining a special counsel for the trial, ${ }^{90}$ there is no indication that he would have had the opportunity to monitor effectively the offending papers. Nor would it have been appropriate for the district court to attempt to determine whether Pavelic had had such an opportunity; the Advisory Committee Note cautioned that " $[t] o$ assure that the efficiencies achieved through more effective operation of the pleading regimen will not be offset by the cost of satellite litigation over the imposition of sanctions, the court must to the extent possible limit the scope of sanction proceedings to the record," ${ }^{, 91}$ and that record would be most unlikely to provide information sufficient to determine the lines of responsibility within a firm.

This is not to say that there were no policy arguments to be made for a Rule that extended sanctions to the signer's law firm. Indeed, in 1993 the rulemakers amended Rule 11 to do just that. However, while Rule 11 now includes an offending attorney's law firm among those who can be sanctioned, ${ }^{92}$ this expansion is balanced by a new provision granting a "safe harbor" of twenty-one days (after service of a Rule 11 motion) within which the offending item can be "withdrawn or appropriately corrected ${ }^{\prime 33}$-a period during which, the Note suggests, the law firm can take measures to avoid the filing of the motion. ${ }^{34}$ Even had it been otherwise appropriate for the Pavelic Court to extend Rule 11 to law firms, the Court presumably could not have offset that extension with the sort of safe harbor created by the rulemakers.

To Judge Moore, however, the Pavelic Court wasted an opportu-

${ }^{90}$ See Calloway, 854 F.2d at 1480 (stating that Pavelic "was no passive observer in the ... litigation," because he “'often discussed' the case with LeFlore, ... he attended several depositions and days of trial, and ... he insisted that Raymond $L$. Levites be retained as special counsel for the trial").

${ }^{91}$ FED. R. CIV. P. 11 advisory committee's note (1983).

92 FED. R. CIV. P. 11 (c) (1993). To underline the change, the Note cited Pavelic and stated that " $[\mathrm{t}]$ his provision is designed to remove the restrictions of the former rule." FED. R. CIV. P. 11 advisory committee's note (1993).

${ }^{93}$ FED. R. CIV. P. 11 (c) (1) (A) (1993).

${ }^{94}$ See FED. R. CIV. P. 11 advisory committee's note (1993) ("Since such a motion may be filed only if the offending paper is not withdrawn or corrected within 21 days after service of the motion, it is appropriate that the law firm ordinarily be viewed as jointly responsible under established principles of agency."). In addition, the 1993 version of Rule 11 provides that in "exceptional circumstances" a law firm can be exempted from liability for violations committed by its partners, associates, and employees. FED. R. CIV. P. 11 (c) (1) (A) ("Absent exceptional circumstances, a law firm shall be held jointly responsible for violations committed by its partners, associates, and employees."). It seems possible that this exception might have protected Pavelic from being held responsible for LeFlore's violations. 
nity to take a "formative role . . in the development of the Rules." Specifically, Moore recognizes that policy arguments could cut either way in Pavelic, ${ }^{\mathbf{9 6}}$ but argues that "given the absence of any empirical evidence supporting either hypothesis as to the effects of imposing sanctions upon the firm, it should be within the trial judge's power to impose sanctions on a law firm as well as (or instead of) the individual attorney signer." pirical data would support a judicial extension of the Rule. She does, however, make clear that her proposed approach would authorize such an extension. Pavelic thus nicely illustrates the practical effects of Moore's thesis that the Court should have more latitude in interpreting the Rules because it is charged with promulgating them. With this example in hand, I now turn to the theoretical problems with that thesis.

\section{A. The Rules Enabling Act's Conditional Transfer of Power}

Interpretive arguments based on the Court's rulemaking power might take two general forms. First, Congress's delegation of rulemaking power to the judiciary might be thought to enlarge the Court's interpretive powers. Second, to the extent that the Court possesses inherent rulemaking authority, it might be argued that such authority justifies the Court in taking a more policy-oriented approach to the interpretation of Rules promulgated pursuant to the Enabling Act. This Section discusses each of these contentions and concludes that neither accords with the rulemaking structure set by the Enabling Act.

The Enabling Act unquestionably transfers lawmaking power from Congress to the judicial branch. ${ }^{98}$ Amendments promulgated pursuant to the rulemaking process take effect, after the report-and-wait period, unless Congress enacts legislation to the contrary. Congress's failure to block the initial set of Rules, and its similar inaction with respect to the 1983 and 1993 amendments, illustrates that amendments

${ }^{95}$ Moore, supra note 3, at 1097.

${ }^{96}$ On one hand, Moore argues, limiting sanctions to the individual signer may help ensure individual compliance with Rule 11; on the other, allowing sanctions against the firm may cause firms to monitor their attorneys' behavior. Moore does not explain why the extension of sanctions to law firms would induce effective monitoring in two-person firms comprising one litigator and one transactional lawyer.

${ }^{97}$ Moore, supra note 3, at 1098-99.

${ }^{98}$ The argument that such power was already part of the Court's inherent authority is addressed below. See infra notes $122-34$ and accompanying text. 
can take effect despite significant congressional opposition.9 ${ }^{99}$ The Rules Enabling Act thus somewhat resembles statutes that delegate rulemaking authority to agencies: rules made by an agency have the force of law unless invalidated by judicial review ${ }^{100}$ or nullified by legislation. There are salient differences, however. For example, although "the transfer of lawmaking authority from Congress-with-the-President (the Article I, Section 7 structure) to agencies significantly increases the importance of the President's preferences in the lawmaking process" (because "agencies are influenced or even controlled by the President"), ${ }^{101}$ agency rulemaking claims democratic legitimacy because the President is "directly accountable to the people." 102 By contrast, the Rules Enabling Act--by delegating rulemaking authority to the judiciary-privileges the decisions of a less politically accountable branch. $^{103}$

An advocate of interpretive discretion might contend that the Enabling Act actually removes a countermajoritarian difficulty present in other interpretive contexts: in this view, since unelected judges promulgate the Rules, no decrease in democratic accountability occurs if an unelected judge contradicts a Rule's text, for policy reasons, when interpreting a Rule. The structure established by the Enabling

${ }^{99}$ See supra text accompanying notes 56-69 (discussing opposition to past sets of rules and noting reasons the opposition failed); see also Burbank, supra note 60, at 1948 (noting that the 1983 amendments "only barely escaped the bright light of the democratic process"). Although the 1988 amendments to the Enabling Act gave Congress more time to consider proposed amendments, it nonetheless failed to enact legislation to block the 1993 amendments from taking effect. See supra text accompanying notes 64-69 (discussing the ineffectual opposition to the 1993 amendments).

${ }_{100}$ As discussed in Part III.A below, judicial review of rulemaking under the Rules Enabling Act has thus far proven largely meaningless.

${ }^{101}$ William N. Eskridge, Jr., \& John Ferejohn, The Article I, Section 7 Game, 80 GEO. L.J. 523, 535 (1992).

${ }^{102}$ Chevron U.S.A. Inc. v. Natural Res. Def. Council, Inc., 467 U.S. 837, 865 (1984); see also, e.g., WILLIAM N. ESKRIDGE, JR., ET AL., CASES AND MATERIALS ON Legislation: Statutes and THE CREATION OF Public POlicy 1068 (3d ed. 2001) (noting that "Chevron rests the idea of deference on the greater democratic legitimacy that agencies enjoy over courts in making policy choices that have been left open by Congress").

${ }^{03}$ See, e.g., Charles Gardner Geyh, Paradise Lost, Paradigm Found: Redefining the Judiciary's Imperiled Role in Congress, 71 N.Y.U. L. REV. 1165, 1244 (1996) ("Agencieseven so-called 'independent' agencies-are politically accountable in ways that the judiciary is not."); John F. Manning, Constitutional Structure and Judicial Deference to Agency Interpretations of Agency Rules, 96 COLUM. L. REV. 612, 675 n.302 (1996) ("The effectiveness of congressional oversight of administrative agencies is hotly contested among political scientists... What is obvious, however, is that Congress necessarily exercises more effective control over administrative agencies than over the judiciary."). 
Act, however, forecloses this argument. ${ }^{104}$ The 1988 amendments, in particular, were designed to "encourage participation [in the rulemaking process] by a broad segment of the community." ${ }^{105}$ Accordingly, the Enabling Act requires that the public be given notice and the opportunity to attend the meetings of the Advisory and Standing Committees, and it mandates public access to the committee minutes. ${ }^{106}$ Proposed amendments circulate to over 10,000 individuals and organizations; in the case of a controversial proposal, circulation often elicits numerous comments, each of which-to the extent feasible-receives a response from the rulemakers. ${ }^{107}$ The Advisory Committee reconsiders its proposals in the light of the public's critiques, and if it makes substantial changes it may recirculate the proposal for further public consideration. A court faced with an interpretive question in the context of litigation could not-even were it so inclinedprovide such extensive opportunities for public input. Similarly, if the Court departed from the text and Notes of a Rule to serve its views of purpose and policy-as Moore advocates-such an interpretive practice would contravene the decision-making structure set by the Enabling Act. Although the Act continues to state that "[ $t]$ he Supreme Court shall have the power to prescribe" the Rules, ${ }^{108}$ this authorization is subject to the "method of prescribing" set forth in the Act. ${ }^{109}$ That method-as discussed in Part I-entails a deliberative, multi-

${ }^{104}$ Cf. Eileen A. Scallen, Classical Rhetoric, Practical Reasoning, and the Law of Evidence, 44 AM. U. L. REV. 1717, 1739-40 (1995) (noting Judge Moore's argument concerning the Federal Rules of Civil Procedure, and rejecting a similar argument concerning the Federal Rules of Evidence).

${ }^{105}$ H.R. REP. NO. 99-422, at 26 (1985).

${ }^{106}$ See supra Part I.D (discussing ways in which the 1988 amendments to the Rules Enabling Act foster public access and input). lic comment).

${ }^{107}$ See id. (describing the process of circulation of proposed amendments for pub-

${ }^{108} 28$ U.S.C. $\$ 2072$ (a) (1994). A previous proposal would have removed this authority. As the House Report on the bill that would form the basis for the 1988 revisions explained:

The original bill in the 98 th Congress ... provided that the Judicial Conference... rather than the Supreme Court, had the authority to promulgate the rules. This approach was thought to respond to the workload concerns of the Court. This suggestion was initially approved by the Supreme Court. After introduction of the bill, concern about this shift in authority was expressed by the Conference of Chief Justices, on behalf of State Supreme Courts. This organization feared that such a move at the federal level would set an unfortunate precedent at the state level. In addition, the Supreme Court itself eventually expressed a preference for retaining its current authority.

H.R. REP. No. 99-422, at 20.

${ }^{109} 28$ U.S.C. $\$ 2073$ (1994) (caption). 
level process ${ }^{110}$ that involves more decision makers than simply the Supreme Court. ${ }^{111}$

The Act does, of course, give the Supreme Court the power to veto a proposed Rule; ${ }^{112}$ but veto power is not a mandate for subsequent revision. As an initial matter, although the Court has on occasion exercised its authority to reject proposed Rules, ${ }^{13}$ it has often appeared to function as a mere "conduit" from the rulemakers to Congress. ${ }^{114}$ Over the years, some Justices have argued that the Court

${ }^{110}$ As noted above, the Act provides for public notice and open meetings; the Act also requires that any Advisory or Standing Committee recommendation include a proposed rule, an explanatory note, and a "written report explaining the body's action, including any minority or other separate views." 28 U.S.C. $§ 2073$ (d) (1994).

${ }^{111}$ Additionally, the Act's report-and-wait requirement gives Congress an opportunity to block proposed Rules before they take effect; by contrast, no such opportunity exists when the Court reinterprets a Rule in the course of deciding a case. Cf. Sara Sun Beale, Reconsidering Supervisory Power in Criminal Cases: Constitutional and Statutory Limits on the Authority of the Federal Courts, 84 COLUM. L. REV. 1433, 1479 n.282 (1984) (noting "clear indications"-in a prior version of Rules Enabling Act-"that legislative rulemaking is intended, such as the requirement that proposed rules be presented to Congress well in advance of their effective date").

${ }^{12}$ This power obviously distinguishes the rulemaking process from congressional legislation. See, e.g., Mistretta v. United States, 488 U.S. 361, 398 n.21 (1989) ("Despite support from Madison, the Framers rejected a proposed 'Council of Revision,' comprised of, among others, a 'convenient number of the National Judiciary,' ... that would have exercised veto power over proposed legislation.") (quoting 1 M. FARRAND, THE RECORDS OF THE FEDERAL CONVENTION OF 1787, at 21 (1911)); Manning, supra note 103, at 643 (noting that the Constitutional Convention "repeatedly rejected proposals for judicial participation in the veto power through a Council of Revision").

${ }^{113}$ Thus, the Court rejected a number of proposed Rules during the first two decades under the Enabling Act. Supra note 11 and accompanying text. A more recent example occurred in 1991, when the Court "refus[ed] to transmit proposed amendments [to Congress] because of foreign relations concerns." Stephen B. Burbank, Ignorance and Procedural Law Reform: A Call for a Moratorium, 59 BROOK. L. REV. 841, 843 (1993).

114 Some Justices clearly do not fit this description, in the sense that they have taken care to dissent from one or more proposed amendments that the Court transmitted to Congress. For example, the order promulgating the original set of Rules noted that "Mr. Justice Brandeis states that he does not approve of the adoption of the Rules." Order of Dec. 20, 1937, 302 U.S. 783, 783 (1937). It appears that Justice Brandeis left no writing that would explain his reasons for dissenting. Some have speculated that they may have related to the opinion Justice Brandeis was soon to write in Erie Railroad v. Tompkins, 304 U.S. 64 (1938). See, e.g., Chandler, supra note 40, at 504 ("It seems probable that [Justice Brandeis's reasons for dissenting] were related to the philosophy of his decision rendered within a few months in April 1938 in Erie Railroad v. Tompkins."). Stephen Burbank, after reviewing the available evidence, has argued that Justice Brandeis's dissent from the promulgation of the Rules arose, not from constitutional objections such as those voiced in Erie, but rather from concerns that the Rules "would unnecessarily displace state law and lead to practical difficulties for lawyers." Letter from Professor Stephen B. Burbank, University of Pennsylvania 
is too busy to scrutinize the substance of proposed amendments. ${ }^{115}$ Others have claimed reliance on the judgment of the Advisory Committee. $^{116}$ When Justices Powell, Stewart, and Rehnquist dissented from the adoption of amendments to the discovery rules in 1980, they advised Congress to "bear in mind that our approval of proposed Rules is more a certification that they are the products of proper pro-

Law School, to Professor Andreas F. Lowenfeld, New York University School of Law 3 (Mar. 6, 1985) (on file with author).

In the years that followed, Justices Black and Douglas regularly dissented, on grounds ranging from constitutional arguments, to Rules Enabling Act concerns, to policy considerations, to a desire to disassociate the Court from the rulemaking process. See, e.g., Order of Dec. 28, 1939, 308 U.S. 642, 642-43 (1939) (adopting an amendment to Rule 81 and noting that Justice Black did not approve); Order of Apr. 17, 1961, 368 U.S. 1012, 1014 (1961) (Douglas, J., dissenting in part) (arguing that Civil Rule 25(d), governing substitution of public officials as parties, should not be amended via rulemaking because its present text was derived from a statute and the rulemaking process was "inappropriate ... for effecting such a basic change in congressional policy as the proposed Rule 25(d) achieves"); Order of Jan. 21, 1963, 374 U.S. 865, 865-66 \& nn.4 \& 5 (1963) (Black \& Douglas, J., dissenting) (arguing that the Enabling Act violated the Constitution's bicameralism and presentment requirements, and that certain proposals violated Enabling Act's terms by affecting substantive rights and by encroaching on the right to trial by jury); Order of Feb. 28, 1966, 383 U.S. 1031, 1032-33 (1966) (Black, J., dissenting) (reiterating bicameralism and presentment argument, and voicing policy concerns about proposed amendments); Order of Feb. 28, 1966, 383 U.S. 1089, 1090 (1966) (Douglas, J., dissenting in part) ("[S] ince under the [enabling statute authorizing promulgation of the Federal Rules of Criminal Procedure] the Rules go to Congress only on the initiative of the Court, I cannot be only a conduit." (citation omitted)); Order of Apr. 24, 1972, 406 U.S. 981, 981 (1972) (Douglas, J., dissenting in part) (dissenting from adoption of proposed criminal rule, in part because "[ $\mathrm{t}]$ here may be several better ways of achieving the desired result"); Order of Apr. 28, 1975, 421 U.S. 1022, 1022 (1975) (Douglas, J., dissenting) (dissenting from adoption of bankruptcy rules and forms under the argument that "[b]ecause this Court is no more than a 'rubber stamp' I think it should not participate in the rulemaking process").

No matter the care with which some dissenters may have scrutinized the amendments, however, there is no basis for ascribing their meticulousness to the majority.

${ }^{115}$ See, e.g., Order of Jan. 27, 1971, 400 U.S. 1031, 1036 (1971) (Black, J., joined by Douglas, J., dissenting) (dissenting from promulgation of Rules of Procedure for the Trial of Minor Offenses Before United States Magistrates because " $[w]$ ith our heavy caseload and the most crowded docket in history there is no use pretending that such rules can or do receive the careful, thoughtful attention of this Court"). In 1979, Chief Justice Burger noted "valid questions as to whether Justices can give proposed rules the kind of close study needed, and whether the Court's approval is really meaningful." Chief Justice Warren E. Burger, Year-End Report on the Judiciary: December 29, 1980, in State of THE Federal Judiciary: ANNUAL REPORTS of THE CHIEF JUSTICE OF THE Supreme Court of THE UNITEd STATES 8-9 (Shelley L. Dowling ed., 2000).

${ }^{116}$ For example, Justice Frankfurter appeared to disclaim responsibility for amendments promulgated in 1946, stating that he joined in approving the amendments "essentially because of his confidence in the informed judgment of the Advisory Committee." Order of Dec. 27, 1946, 329 U.S. 843 (1946). 
cedures than a considered judgment on the merits of the proposals themselves." 117 Likewise, when the Court forwarded the 1993 amendments to Congress, Chief Justice Rehnquist's transmittal letter disclaimed responsibility for the substance of the amendments, stating that " $[w]$ hile the Court is satisfied that the required procedures have been observed, this transmittal does not necessarily indicate that the Court itself would have proposed these amendments in the form submitted."118

In any event, even if the Court did take a uniformly active role in reviewing (and, where appropriate, rejecting) proposed Rules, such a role would not expand the Court's power to alter a promulgated Rule. The Enabling Act permits the Court to maintain the status quo-even if the Advisory Committee, the Standing Committee, and the Judicial Conference wish to alter it-because, if the Court rejects a proposed amendment, only congressional legislation can override the Court's veto. However, the Court is not the only "vetogate" in the rulemaking process. ${ }^{119}$ Should the Court wish to alter a Rule already in force, the Enabling Act does not contemplate that the Court could do so outside the rulemaking structure. ${ }^{120}$ Though the Court, like other entities, can suggest changes for the rulemakers' consideration, ${ }^{121}$ it cannot

117 Order of Apr. 29, 1980, 446 U.S. 997, 998 n.1 (1980) (Powell, J., joined by Stewart \& Rehnquist, JJ., dissenting). The dissenters asserted that the amendments failed to implement necessary reforms, and they argued that "Congress' acceptance of these tinkering changes will delay for years the adoption of genuinely effective reforms" by "creat[ing] complacency and encourag[ing] inertia." Id. at 1000.

118 Letter from William H. Rehnquist, Chief Justice, United States Supreme Court, to Thomas S. Foley, Speaker, United States House of Representatives (Apr. 22, 1993), in 146 F.R.D. 403.

119 See, e.g., William N. ESkridge, JR. ET AL., Legislation AND STATUTORY INTERPRETATION 68 (2000) (describing "vetogates" as "stage[s] in the legislative process" where "a proposal can be changed or halted, new coalitions must be formed, and opportunities for logrolling, strategic behavior, and deliberation are presented"). In using this term, I am conscious that not all aspects of the legislative process generalize to the context of court rulemaking. See, e.g., Robert G. Bone, The Process of Making Process: Court Rulemaking, Democratic Legitimacy, and Procedural Efficacy, 87 GEO. L.J. 887, 924-25 (1999) (arguing that "inefficient logrolling is less likely in a court-based rulemaking process" because the scope of the Advisory Committee's rulemaking covers "a smaller region over which trades can be made").

${ }^{120}$ Admittedly, this was not always the case. In 1956, "the Court, acting on its own and without recommendation of any committee," amended Rule 46 of the Federal Rules of Criminal Procedure. Clark, Role of the Supreme Court, supra note 11, at 257. This event, however, preceded the 1958 and 1988 amendments, which set the current requirements for the rulemaking process.

${ }^{121}$ Thus, for instance, it appears that Chief Justice Burger, having "failed to persuade his colleagues on the Court" to make certain changes to the habeas rules "via case adjudication," wrote "directly to members of the Advisory Committee asking them 
promulgate such changes against the wishes of the other participants in the rulemaking process.

Accordingly, since the Enabling Act conditions the delegation of rulemaking power on the Court's use of the prescribed procedures, it appears to require the Court to resort to those procedures when seeking to change a Rule. The matter is rendered somewhat more complex, however, by the question of the Court's inherent procedural authority. The Supreme Court has asserted that " [c] powers must necessarily result" to the federal courts "'from the nature of their institution,' powers 'which cannot be dispensed with . . . because they are necessary to the exercise of all others." ${ }^{222}$ Advocates of judicial discretion thus might argue that, to the extent the Enabling Act's delegation merely duplicates the courts' inherent powers, courts should have greater latitude to interpret freely the Rules promulgated under the Act. Under this view, the Court can weigh policy considerations when exercising its inherent authority, and it should be accorded the same latitude when interpreting the Rules. This argument, however, overlooks the limits of such inherent powers. Although the question is murky, ${ }^{123}$ and a full treatment of the issues is beyond the scope of this Article, ${ }^{124}$ it is not at all clear that the federal courts' inherent powers include authority to promulgate rules of procedure. ${ }^{125}$ Rather, such inherent authority may be limited to powers necessary to the fulfillment of the courts' Article III responsibilities-a far narrower range than is covered by the current Federal Rules. Moreover, the courts' inherent powers-whatever their initial extent-are subject to Congress's separate authority to regulate federal court procedure. As the Court observed soon after the promulgation

to support" a proposal for similar changes. Letter from Nan Aron, Alliance for Justice, Laura Macklin, Institute for Public Representation, Judith Resnik, University of Southern California Law School, Dennis E. Curtis, University of Southern California Law School, \& William Genego, University of Southern California Law School, to Robert W. Kastenmeier, Chairman, Subcommittee on Courts, Civil Liberties, and the Administration of Justice 2 (June 5, 1985), in Hearing, supra note 37, at 190, 191.

${ }^{122}$ Chambers v. NASCO, Inc., 501 U.S. 32, 43 (1991) (quoting United States v. Hudson, 11 U.S. 21, 23, 7 Cranch 32, 34 (1812)).

${ }^{123}$ See, e.g., Bone, supra note 119 , at $890 \mathrm{n} .12$ (taking "no position on the difficult question whether courts have the constitutional power to make a system of procedural rules in the absence of congressional authorization (or perhaps even in the face of a contrary congressional intent)").

${ }^{124}$ For a recent discussion of the topic, see Robert J. Pushaw, Jr., The Inherent Pow ers of Federal Courts and the Structural Constitution, 86 IOWA L. REV. 735 (2001).

${ }^{125}$ See Burbank, supra note 11, at 1115 (noting that "the power of federal courts to regulate procedure by court rules in the absence of legislative authorization ... has not been made clear" (footnote omitted)). 
of the original Rules, "Congress has undoubted power to regulate the practice and procedure of federal courts, and may exercise that power by delegating to this or other federal courts authority to make rules not inconsistent with the statutes or constitution of the United States." So long as Congress's regulation of federal procedure does not "prevent[] a court from discharging its Article III duties," ${ }^{27}$ Congress's directives trump contrary principles adopted by the Supreme Court pursuant to its inherent authority. Accordingly, the prior existence of inherent judicial authority concerning a particular matter likely will be rare (given the apparent bounds of such authority) and should, in any event, be irrelevant to the Court's interpretation of a Rule governing the matter.

Although the Court has not claimed that inherent powers expand its license to consult its policy inclinations when interpreting the Rules, it might attempt a similar maneuver using a different rationale. In Chambers $v$. NASCO, Inc., the Court held that neither 28 U.S.C. $\S 1927$ nor any of the Federal Rules of Civil Procedure "displaces the inherent power to impose sanctions for the bad-faith conduct" of a party to litigation. ${ }^{128}$ The Court acknowledged that "the exercise of the inherent power of lower federal courts can be limited by statute and rule, for '[ $\mathrm{t}]$ hese courts were created by act of Congress," "129 but it

${ }^{126}$ Sibbach v. Wilson \& Co., 312 U.S. 1, 9-10 (1941) (footnote omitted). Sibbach's specification that the rules be "not inconsistent" with federal statutes is intriguing, given that the Enabling Act contained a supersession clause which provided (in its then-current form) that "all laws in conflict [with the Rules] shall be of no further force or effect." Act of June 19, 1934, $\$ 1,48$ Stat. 1064, 1064 (current version at 28 U.S.C. $\$ 2072$ (1994)).

The Enabling Act has been criticized, on the one hand, for involving the Court in "the adoption of legislation," see MARTIN H. REDISH, FEDERAL JURISDICTION: TENSIONS in THE Allocation of Judicial POWER 21 (2d ed., Michie Co. 1990) (1980) (arguing that the Rules Enabling Act violates separation of powers), and on the other, for trespassing on judicial prerogatives, see David E. Engdahl, Intrinsic Limits of Congress' Power Regarding the Judicial Branch, 1999 BYU L. REV. 75, 172 (arguing that the Enabling Act "is subject to serious constitutional doubt" because it constrains the courts' "rulemaking competence"); cf. John H. Wigmore, All Legislative Rules for Judiciary Procedure Are Void Constitutionally, 23 ILL. L. REV. 276, 278 (1928) (asserting that "the legislature has no more constitutional business to dictate the procedure of the judiciary than the judiciary has to dictate the procedure of the legislature"). This Article's discussion, however, proceeds on the assumption that the Enabling Act is constitutional. See, e.g., Weinstein, supra note 19 , at 927 (noting that "Congress" position as possessor and delegator of the rulemaking power" is well established).

${ }^{127}$ Pushaw, supra note 124, at 792 n.287.

128501 U.S. 32, 46 (1991).

${ }^{129}$ Id. at 47 (alteration in original) (quoting Ex parte Robinson, 86 U.S. (19 Wall.) $505,511(1874))$. 
appeared to impose a clear statement requirement on the rulemakers. Thus, the Court will not "'lightly assume [an intent] to depart from established principles' such as the scope of a court's inherent power," absent "a much clearer expression of purpose" showing that the Rule "was intended to abrogate so well-acknowledged a proposition." "131 To the extent that such a clear statement rule functions as a one-way ratchet-providing for the application of Rules that empower courts but mandating the narrow construction of Rules that otherwise would limit inherent authority-it is at best an unseemly canon of interpretation. As the Court has acknowledged, " $[t]$ he extent of [courts' inherent] powers must be delimited with care, for there is a danger of overreaching when one branch of the Government, without benefit of cooperation or.correction from the others, undertakes to define its own authority." ${ }^{132}$ Especially in light of the participation of trial and appellate judges in the rulemaking process, there is no reason to set a clear statement rule as a way to protect inherent judicial power from encroachment by the rulemakers. ${ }^{133}$ Just as "[p] rinciples of deference counsel restraint in resorting to inherent power," statement requirement on Rules that limit inherent authority.

${ }^{130}$ Id. (quoting Weinberger v. Romero-Barcelo, 456 U.S. 305, 313 (1982)). Although Weinberger concerned the interpretation of a statute, the Chambers Court's discussion elides the issues of statutory and Rules interpretation. See id. at 47-49 (concluding that neither the rulemakers' 1983 amendments to Rule 11 nor Congress's 1980 amendments to 28 U.S.C. $\$ 1927$ removed the lower federal courts' inherent authority to sanction litigants).

${ }^{131} I d$. at 49 (quoting Link v. Wabash R.R. Co., 370 U.S. 626, 631-32 (1962)).

132 Degen v. United States, 517 U.S. 820, 823 (1996).

${ }^{133}$ It might be argued that such a clear statement rule reflects the likelihood that the judges who participate in the rulemaking process do not intend to infringe on the judiciary's inherent powers. In this view, because rulemakers are likely to be protective of existing judicial powers, it is realistic to presume-absent a clear statement to the contrary-that a Rule is not intended to infringe on such powers. This argument, however, assumes that the relevant intent is solely that of the judges who participate in the rulemaking process. Not all those who serve on the Advisory Committee and Standing Committee are judges; and Congress, which has the opportunity to review proposed Rules before they take effect, is unlikely to share judges' solicitude for judicial powers. If anything, the participation of judges at the levels of the Advisory Committee, Standing Committee, Judicial Conference, and Supreme Court suggests that the rulemakers will be well able to include language to protect judicial authority, if that is the desired result; accordingly, no clear statement rule should be necessary.

${ }^{134}$ Degen, 517 U.S. at 823. 


\section{B. The Responsive Nature of the Rulemaking Process}

In addition to the limits imposed by the Rules Enabling Act itself, the relative ease with which amendments may be promulgated through the rulemaking process counsels restraint in judicial interpretation of the Rules. Changed circumstances, which provide one argument for judicial modification of statutory provisions, fail to provide similar support for judicial revision of the Rules. ${ }^{135}$ Because the constitutional requirements of bicameralism and presentment "make[] it hard to enact or amend statutes, they must usually last for a long time." ${ }^{136}$ Over the years, circumstances may render the literal language of the statute, as originally drafted, undesirable-because "the factual assumptions underlying the original statute [are] no longer ... valid," the statutory provision is "no longer . . . consistent with widely held social norms," or "the legal background [has] changed dramatically as a result of legislative and administrative innovations." ${ }^{197}$ Thus, advocates of dynamic statutory interpretation have argued that " [a]n important reason for having an independent judiciary is to reassure Congress that the statutes it enacts will remain efficacious over time and not run wild or expire because of the inattention of subsequent Congresses." 138 Courts, when asked to apply a statute to the facts of the case at hand, have "the ability to consider carefully the consequences of adopting competing interpretations, the effect of postenactment developments, and the relevance of applications unforeseen by the legislature." 139 Even apart from legislative inertia, "it may be unrealistic to expect Congress to monitor every nook and cranny of statutory policy from year to year, for that is the reason why Congress delegates policy-making authority to agencies and courts." ${ }^{140}$ Thus, commentators have argued that judges "must often exercise creativity

${ }^{135}$ Lars Noah has made a similar argument with respect to agencies' interpretations of legislative rules. See Lars Noah, Divining Regulatory Intent: The Place for a "Legislative History" of Agency Rules, 51 HASTINGs L.J. 255, 296-97 (2000) ("If a legislative rule must evolve to meet unforeseen contingencies, the agency has the means at its disposal to revise the regulation directly, so courts need not tolerate the subterfuge of a newly revised interpretation of the original text to accomplish the same end.").

${ }^{136}$ WILliAM N. ESKRIDGE, JR., DYNAMIC STATUTORY INTERPRETATION 50 (1994).

137 Cass R. Sunstein, Interpreting Statutes in the Regulatory State, 103 HARV. L. REV. 405, 494-95 (1989).

138 ESKRIDGE, supra note 136 , at 131.

${ }^{139}$ Jane S. Schacter, Metademocracy: The Changing Structure of Legitimacy in Statutory Interpretation, 108 HARV. L. REV. 593, 627 (1995).

${ }^{40}$ ESKRIDGE, supra note 136, at 131. 
in applying prior legislative directives to specific situations"141 and that judges should seek "'to say what the legislator would have said had he been present, and would have put into law if he had known." 142 Moore has applied similar arguments to the interpretation of Rules, arguing that "Rules should be interpreted to reflect changed circumstances," and that "[a]ffording the Court flexibility in considering policy is particularly important when the issue in a case concerns matters unanticipated at the time of the framing of the Rule."143

Moore's treatment of the obsolescence argument, however, neglects key differences between the legislative and rulemaking processes. ${ }^{144}$ There is little need for courts to speculate how past rulemakers would have dealt with present circumstances because the Advisory Committee and the Standing Committee exist expressly to "carry on a continuous study of the [Rules'] operation and effect."145 "Nor do the rulemakers display legislative inertia: ${ }^{146}$ in the sixty-three years since the adoption of the Rules, the rulemaking process has produced some twenty-four packages of revisions to the Rules, ${ }^{147}$ including-since the 1988 amendments to the Enabling Act-eight packages of amendments affecting thirty-five different Rules. ${ }^{188}$ Moore acknowledges that Rules can also be changed by the rulemakers, but prefers alteration via judicial decision because "amendments have to work their way

\section{Id. at 125.}

${ }^{142}$ Id. at 50 (quoting ARISTOTLE, THE NICOMACHEAN ETHICS, bk. 5, ch. 10 (W.D. Ross trans., 1984)).

${ }^{143}$ Moore, supra note 3 , at $1094-95$.

144 Leslie Lunney has made a similar point with respect to the interpretation of the Federal Rules of Evidence. See Leslie A. Lunney, Protecting Juries from Themselves: Restricting the Admission of Expert Testimony in Toxic Tort Cases, 48 SMU L. REV. 103, 116-17 (1994) ("By creating a specific mechanism to amend the Rules, Congress intended the judiciary to follow the procedure detailed in the [Rules Enabling] Act to implement changes in the Rules if such changes should appear necessary or desirable.").

28 U.S.C. $\$ 331$ (1994).

${ }^{146}$ Indeed, in 1993 "the pace of proposed amendments" led Stephen Burbank to caution that " $[t]$ he 'continuous study of the operation and effect' of Federal Rules ... need not be, and it should not be, construed as an invitation to '[c] onstant reform.'” Burbank, supra note 113, at 854 (quoting 28 U.S.C. $\$ 331$ ) .

147 See 12A Arthur R. Miller et al., Federal Practice and Procedure app. B at $72-73$ (2001) (listing amendments to Rules). This figure counts (as one package) the rules and amendments promulgated by the Court in November and December 1972, even though Congress rejected or modified some of the proposed evidence rules and enacted legislation adopting the remainder of the rules. The number does not include Rules changes made via legislation.

${ }^{148}$ This figure actually undercounts the number of Rules affected by each set of amendments because it counts only once each Rule that has been amended since 1988. 
through the often time-consuming rulemaking process," and to wait for a formal amendment would "deprive the litigants of a fair and just result in their case." ${ }^{149}$ However, amendments normally take no more than two or three years to emerge from the rulemaking process; ${ }^{150}$ the pace of change via Supreme Court review of lower court decisions surely cannot be much faster.

Moreover, Moore's preference for change via Supreme Court interpretation fails to take account of the Supreme Court's position in the rulemaking framework. Admittedly, the responsiveness of the rulemaking process at first glance might seem to cut both ways on the question of interpretation: although the rulemakers stand ready to respond to changed circumstances-thus perhaps obviating the need for dynamic judicial interpretation-they can also correct erroneous interpretations by the Court-thus possibly removing concerns about judicial activism. Under the latter view, the Court need not scruple to adhere closely to the Rule as drafted, because if it strays from the current preferences of the rulemakers the Rule can readily be amended. ${ }^{151}$ For example, the effect of the Court's expansive reading of Rule 11 in Cooter $\mathcal{F}^{2}$ Gell v. Hartmarx Corp. ${ }^{152}$ - to reach a litigant that had voluntarily dismissed its action-was tempered substantially by the 1993 amendments' provision of a safe harbor and limitations on court-initiated monetary sanctions. ${ }^{153}$ There is, however, an asymmetry to the Court's involvement in the rulemaking process. A Court that wishes to change a Rule, but resists doing so via interpretation, will support (and transmit to Congress) a proposed amendment that effects the desired change; but a Court that has changed a Rule via in-

${ }^{149}$ Moore, supra note 3, at 1095.

${ }^{150}$ Mecham, supra note 35 ("From beginning to end, it usually takes two to three years for a suggestion to be enacted as a rule.").

${ }^{151}$ See Moore, supra note 3, at 1097 (supporting the argument for a "flexible approach to interpretation" by noting that "if the Court errs ... the normal rulemaking process or direct congressional intervention (in rare instances) would be available to put the Rules back on track").

${ }^{152} 496$ U.S. 384 (1990).

${ }^{153}$ In Cooter $\mathcal{F}^{\circ}$ Gell, the Court took an expansive view of the district court's authority to impose Rule 11 sanctions, holding that district courts may impose Rule 11 sanctions even after the plaintiff files a notice of dismissal under Rule 41 (a) (1) (i). Id. at 395. This ruling created a risk that plaintiffs might be "sandbagged" by a court's unexpected post-dismissal imposition of sanctions. The 1993 amendments to Rule 11 address this problem in two ways: the safe harbor provision protects a plaintiff from sanctions motions filed after a voluntary dismissal, and court-initiated monetary sanctions cannot be awarded "unless the court issues its order to show cause before a voluntary dismissal or settlement of" the pertinent claims. FED. R. CIV. P. 11(c)(2)(B) (1993). 
terpretation may be reluctant to approve a proposed amendment that would undo its work. The behavior of some current members of the Court suggests that this concern is not fanciful: although a majority of the Court did vote to transmit the 1993 amendments to Rule 11, one of the reasons given by Justices Scalia and Thomas for dissenting from the transmittal was that the amendments "contradict[] what this Court said only three years ago" in Cooter $\mathcal{F}^{2}$ Gell. ${ }^{154}$

\section{Other Advantages of the Rulemaking Process}

On first consideration, it might seem that, to the extent that the Supreme Court is involved in the rulemaking process, it is well qualified to make choices concerning changes to the Rules. ${ }^{155}$ Compared with the other rulemaking bodies, however, the Court appears less representative, less knowledgeable, and perhaps more liable to engraft erroneous policy choices on the Rules. As noted above, since 1988 Congress has required that any Advisory Committee created under the Enabling Act include "members of the ... professional bar" as well as "trial and appellate judges." Though the Civil Rules Advisory Committee has sometimes lacked a strong practitioner presence, ${ }^{157}$ the statutory requirement at least ensures representation of some segments of the bar, and the notice-and-comment process permits input from others. ${ }^{158}$ By contrast, members of the Court may be more sensitive to the interests of the judiciary than to those of litigators, ${ }^{159}$ and-

${ }^{154}$ Amendments to the Federal Rules of Civil Procedure, 146 F.R.D. 507, 508 (1993) (Scalia, J., joined by Thomas, J., dissenting in part).

155 Indeed, the Court has accepted a similar argument in the context of agency rulemaking. "[W]hen an agency interprets a regulation that it has promulgated... the Court has explained [that] the agency is in 'a better position . . . to reconstruct the purpose of the regulations in question,' in part because of its 'historical familiarity' with the reasons for adopting the text in question." Manning, supra note 103, at 630 .

${ }^{156} 28$ U.S.C. $\$ 2073(\mathrm{a})$ (2) (1994).

${ }^{157}$ See, e.g., Laura A. Kaster \& Kenneth A. Wittenberg, Rulemakers Should Be Litigators, NAT'L L.J., Aug. 17, 1992, at 15-16 (“Today, of the committee's 12 members, six are judges, three are law professors, one is a representative of the Justice Department and only two are private practitioners.").

${ }^{158}$ Similarly, the Standing Committee currently includes a mix of district and court of appeals judges and practitioners. In addition, legal academics serve on both the Advisory and Standing Committees.

${ }^{159}$ Thus, for instance, Justices Scalia and Thomas, dissenting from the transmission of the 1993 amendments, were quick to dismiss the views of the "many lawyers [who] do not like Rule 11," and relied instead upon alleged "overwhelming approval of the Rule by... federal district judges." See Amendments to the Federal Rules of Civil Procedure, 146 F.R.D. at 509, 510 (Scalia, J., joined by Thomas, J., dissenting in part). Though there are few empirical data on judges' preferences, $c f$. Jonathan $R$. 
as Justice Douglas noted years ago-the Court may lack relevant expertise compared with practitioners and lower court judges. ${ }^{160}$ A lack of personal experience, moreover, will not necessarily deter members of the Court from assessing the Rules in the light of their intuitions ${ }^{161}$

Macey, Judicial Preferences, Public Choice, and the Rules of Procedure, 23 J. LEGAL STUd. 627, 628 (1994) (noting that "the existing economic literature on the rules of procedure uniformly has ignored the possibility of self-interest" on the part of judges); $i d$. at 631 (developing "hypotheses about judicial preferences"); Richard A. Posner, What Do Judges and Justices Maximize? (The Same Thing Everybody Else Does), 3 S. CT. ECON. REV. 1, 2 (1993) (modeling the utility function of federal appellate judges as "a function mainly of income, leisure, and judicial voting"), it is not implausible to argue, for example, that "judges have a vested interest in reducing the workload of the courts, and they may attempt to advance that agenda without sensitivity to the impact on the system as a whole, particularly the impact on the attorney-client relationship." Kaster \& Wittenberg, supra note 157, at 16; see also Burbank, supra note 113, at 848 (suggesting that experience with "Rule $11, \ldots$ sanctions in general, ... court-annexed arbitration [, and] managerial judging" illustrates the conflict between "the interests of the judiciary narrowly viewed" and other interests); Stephen B. Burbank, Procedure and Power, 46 J. LEGAL EDUC. 513, 515 (1996) (noting "a view long held by some scholars ... that in making and applying procedural law judges attend to their own professional interests as well as to the interests of practicing lawyers, litigants, and society").

${ }^{160}$ See, e.g., Order of Apr. 22, 1974, 416 U.S. 1003, 1003 (1974) (Douglas, J.) (noting his opposition, with respect to proposed criminal rules, "to the Court's being a mere conduit of Rules to Congress since the Court has had no hand in drafting them and has no competence to design them"); Order of Apr. 24, 1973, 411 U.S. 992, 994 (1973) (Douglas, J., dissenting) ("I know enough about history, our Constitution, and our decisions to oppose the adoption of Rule 920 . But for most of these Rules I do not have sufficient insight and experience to know whether they are desirable or undesirable. I must, therefore, disassociate myself from them."); Order of Nov. 20, 1972, 409 U.S. 1132, 1132-33 (1972) (Douglas, J., dissenting) (voicing doubts whether "rules of evidence are within the purview" of $\$ 2072$, and arguing that the Court is "so far removed from the trial arena that we have no special insight, no meaningful oversight to contribute").

Indeed, much of the litigation activity governed by the Rules currently takes place outside the supervision of district judges and magistrate judges; thus, even trial level judges may lack firsthand knowledge of the relevant issues. At any rate, the cases that come before the Court are unlikely to reflect many of the realities of trial level litigation; but to the extent that they do, the limited nature of the Court's docket is likely to skew its awareness of current practices and problems. Judge Weinstein has suggested that a similar bias might color the Court's assessment of proposed amendments to the Rules. See Jack B. Weinstein, Reform of Federal Court Rulemaking Procedures, 76 CoLum. L. REV. 905, $934 \mathrm{n} .188$ (1976) ("In the areas both of work product and privilege, contemporaneous litigation had apparently sharpened the Court's awareness of the subtleties involved, making it less eager to adopt categorical rules.").

${ }^{161}$ To the extent that the Court perceives itself to have expertise in matters of litigation procedure, this perception might induce overconfidence, thus leading the Court to unwarranted boldness in implementing its views of desirable policy. See generally Chris Guthrie et al., Inside the Judicial Mind, 86 CORNELL L. REV. 777, 813 (2001) (positing that "[e]gocentric biases could lead judges to believe that they are better decision makers than is really the case"); Adrian Vermeule, Interpretive Choice, 75 N.Y.U. L. REv. 74, 118 \& n.172 (2000) (noting "cognitive biases that afflict experts, such as over- 
or policy preferences. ${ }^{162}$

The dissents from the transmittal of the 1993 amendments lend support to such concerns. Justices Scalia and Thomas dissented from the transmittal of the amendments to Rule $11,{ }^{163}$ complaining that

[t]he proposed revision would render the Rule toothless, by allowing judges to dispense with sanction, by disfavoring compensation for litigation expenses, and by providing a 21-day "safe harbor" within which, if the party accused of a frivolous filing withdraws the filing, he is entitled to escape with no sanction at all. ${ }^{164}$

To support this view, Justice Scalia made some predictions concerning the behavior of district judges:

Judges, like other human beings, do not like imposing punishment when their duty does not require it, especially upon their own acquaintances and members of their own profession. They do not immediately see, moreover, the system-wide benefits of serious Rule 11 sanctions, though they are intensely aware of the amount of their own time it would take to consider and apply sanctions in the case before them.

These observations-for which Justice Scalia cited no authoritycontrast somewhat with his own description of data gathered by the Federal Judicial Center. To support his argument that "there appears to be general agreement ... that Rule 11, as written, basically works," Justice Scalia summarized data from a Federal Judicial Center survey

confidence"). Of course, members of the Advisory Committee and other rulemaking decision makers may experience similar cognitive illusions, but the rulemaking process likely helps to counterbalance decision makers' overconfidence by providing an opportunity for empirical study and by requiring review by more than one deliberative body as well as public notice and comment.

${ }^{162}$ Of course, even within the rulemaking process, a majority of the Court could block proposed amendments favored by the other rulemaking bodies; but it could not implement amendments against the wishes of those bodies.

${ }^{163}$ In addition, Justices Scalia, Thomas, and Souter dissented from the transmittal of the discovery-related amendments, terming them "potentially disastrous and certainly premature," and arguing that they would "increase litigation costs, burden the district courts, and, perhaps worst of all, introduce into the trial process an element that is contrary to the nature of our adversary system." 146 F.R.D. 507, 507, 510 (dissenting statement of Scalia, J., joined in pertinent part by Thomas and Souter, JJ.).

${ }^{164}$ Id. at 507-08 (dissenting statement of Scalia, J., joined by Thomas, J.).

${ }^{165}$ Id. Although Justice Scalia did not suggest the existence of any data to support these assertions, the topic would form an interesting basis for empirical study. Cf., e.g., Guthrie et al., supra note 161, at 805, 810 (noting that the representativeness heuristic "can lead people to discount relevant statistical information," and arguing that the use of this heuristic has sometimes "led judges to create erroneous legal doctrine"). It is intriguing that Justice Scalia-having implicitly acknowledged that such heuristics can distort judicial decision making-nonetheless rested his objections to the amended Rule 11 on survey responses by district judges. Infra text accompanying notes 166-67. 
showing that " $80 \%$ of district judges believe Rule 11 has had an overall positive effect and should be retained in its present form ... and about $75 \%$ said the benefits justify the expenditure of judicial time" pose Rule 11 sanctions. Justice Scalia acknowledged that the "general agreement" to which he referred did not exist among lawyers, but concluded that "the overwhelming approval of the Rule by the federal district judges who daily grapple with the problem of litigation abuse is enough to persuade me that it should not be gutted as the proposed revision suggests." 167

Justice Scalia's arguments prompted Justice White-who also wrote a statement - to chide the dissenters for second-guessing the drafting and approval process:

I did my share of litigating when in practice and once served on the Advisory Committee for the Civil Rules, but the trial practice is a dynamic profession, and the longer one is away from it the less likely it is that he or she should presume to second-guess the careful work of the active professionals manning the rulemaking committees, work that the Judicial Conference has approved .... .

Justice Douglas ... refused to be a mere conduit and would dissent to forwarding rule changes with which he disagreed. I note that JUSTICE SCALIA seems to follow that example. But I also note that as time went on, Justice Douglas confessed to insufficient familiarity with the context in which new rules would operate to pass judgment on their merits. ${ }^{168}$

In response, Justice Scalia admitted to a lack of trial experience, but nonetheless claimed competence to assess the amendments:

Never having specialized in trial practice, I began at the level of expertise (and of acquiescence in others' proposals) with which Justice Douglas ended. Both categories of revision on which I remark today, however, seem to me not matters of expert detail, but rise to the level of principle and purpose that even Justice Douglas in his later years continued to address. It takes no expert to know that a measure which eliminates rather than strengthens a deterrent to frivolous litigation is not what the times

${ }^{166} 146$ F.R.D. at 509 (citing INTERIM REPORT, supra note 38, reprinted in VAIRO, supra note 38 , app. at I-8 to I-10). Justice Scalia's summary of the data provided in the Interim Report was somewhat incomplete. For instance, his dissent did not mention that the judges apparently were surveyed before the proposed amendments had been circulated: thus, as the Interim Report observed, " $[\mathrm{t}]$ he relatively low proportion of judges ... who favor some revision of the rule ... may indicate not so much an aversion to amendment as a desire to keep the basic principles intact and the lack of any particular amendment to consider." INTERIM REPORT, supra note 38, reprinted in VAIRO, supra note 38 , app. at I-10.

167 146 F.R.D. at 509-10.

${ }^{168}$ Id. at 504-05 (statement of White, J.). 
demand .... ${ }^{169}$

Admittedly, the Scalia/Thomas view failed to carry the day with respect to the 1993 amendments; but the tendencies evident in the dissent may influence the decisions of some Justices in other situations. Requiring that changes take place through the rulemaking process-rather than through adjudication-at least increases the chances that amendments will be subjected to a deliberative process and informed by practical knowledge. In addition, the structure of the rulemaking process facilitates informed and deliberative decision making and permits a holistic approach to the revision of the Rules. ${ }^{170}$ Although the rulemakers have not always made as much use of this opportunity as they could, ${ }^{171}$ the rulemaking process clearly affords better access to empirical data than does adjudication. ${ }^{172}$ It also provides a better framework for input by all interested persons and allows the rulemakers to revise their proposals in response to such input. Moreover, the rulemakers can amend several provisions at the same time, which helps maintain coherence in the Rules ${ }^{179}$ and permits finetuning of proposed changes. The 1993 amendments to Rule 11 provide a good example. In Pavelic, the Court had refused to hold that the 1983 version of Rule 11 permitted sanctions against the law firm of

${ }^{169} 146$ F.R.D. 507, 513 (Scalia, J., joined by Thomas, J., dissenting in part).

${ }^{170}$ Colin Diver has made a similar distinction between agency rulemaking and agency adjudication: in adjudication

going beyond the case at hand requires the agency to expend resources investigating additional factual and policy issues. A private litigant is rarely willing to assist in that effort, for the benefits will accrue primarily to others. Indeed, a litigant seeking prompt results has a keen interest in minimizing the scope of investigation.

Colin S. Diver, Policymaking Paradigms in Administrative Law, 95 HARv. L. REv. 393, 40304 (1981).

${ }^{171}$ For example, with respect to the 1983 amendments to Rule 11,

[t]he Advisory Committee knew little about experience under the original Rule, knew little about the perceived problems that stimulated the efforts leading to the two packages of Rules amendments in 1980 and 1983, knew little about the jurisprudence of sanctions, and knew little about the benefits and costs of sanctions as a case management device.

Burbank, supra note 60, at 1927 (footnotes omitted).

${ }^{172}$ The process followed in drafting the 1993 amendments to Rule 11 is illustrative: the Advisory Committee issued a call for comments, commissioned two empirical studies by the Federal Judicial Center, and held public hearings on the proposed revisions.

${ }^{179}$ Cf. Bone, supra note 119 , at 946 (arguing that procedural rules are "interdependent," and therefore should be "tightly coordinated," because "[p]arties view a lawsuit as a unitary event with a single objective, and they pick their strategies at each stage with an eye to the possible effects at every other stage"). 
an offending attorney. ${ }^{174}$ The 1993 amendments to Rule 11, by contrast, do permit law firm liability, but they also add the "safe harbor" provision that permits the withdrawal of offending papers-a balance that the Court could not have struck had it chosen, in Pavelic, to extend the 1983 version of the rule to law firms. Similarly, under the 1993 amendments, as under Business Guides, Inc. v. Chromatic Communications Enterprises, Inc. ${ }^{175}$ a represented party can be sanctioned; but the amended Rule prohibits the award of monetary sanctions against a represented party for violations concerning legal (as opposed to factual) contentions. ${ }^{176}$

\section{DELEGATION AND INTERPRETIVE SOURCES}

Both the structure of the Enabling Act and the actual rulemaking process, then, counsel restraint in the interpretation of the Rules: the Court should not reject authoritative sources of meaning in favor of its own policy conception of a desirable Rule. This raises the question, however, of what those authoritative sources might be (aside from the text of the Rule). In the context of statutory interpretation, the answer to that question typically varies depending on whether the interpreter is willing to look to purpose or intent, as well as text. This Part does not take sides in that debate (apart from assuming that a purposivist approach would fail to provide answers to most questions of Rules interpretation ${ }^{177}$ ). Rather, it argues for an interpretive approach that proceeds from an awareness of the scope of the Enabling Act

${ }^{174}$ See supra text accompanying notes 83-87 for a discussion of Pavelic.

${ }^{175} 498$ U.S. 533 (1991).

${ }^{176}$ FED. R. CIV. P. 11 (c) (2) (A) (1993).

${ }^{177}$ The statutes and rules that suggest the broad purposes of the Rules are unlikely to resolve most interpretive issues. The relevant statutes direct the Standing Committee to recommend to the Judicial Conference such amendments "as may be necessary to maintain consistency and otherwise promote the interest of justice," 28 U.S.C. $\S 2073$ (b) (1994), and direct the Judicial Conference, in turn, to recommend to the Supreme Court those amendments that seem "desirable to promote simplicity in procedure, fairness in administration, the just determination of litigation, and the elimination of unjustifiable expense and delay," 28 U.S.C. $\$ 331$ (1994). Rule 1, likewise, provides that the Rules "shall be construed and administered to secure the just, speedy, and inexpensive determination of every action." FED. R. CIV. P. 1. Such purposes are likely to yield support for both sides of a given dispute. The aims of speed, simplicity, and inexpensiveness, for example, may counsel one interpretation of a Rule, where the goals of justice and fairness would support another. The observation that arguments from purpose "are usually indeterminate because there is no neutral way to choose a single statutory purpose," ESKRIDGE, supra note 136, at 29, thus applies equally in the context of the Rules; and the interpretive search must proceed to other sources. 
delegation and that gives authoritative weight to the Advisory Committee Notes. Such an approach can be justified on both intentionalist and textualist grounds, and it reflects-to some degree-the methods observable in recent Supreme Court decisions.

Here, again, an example may help to clarify the stakes of the debate. For present purposes, the Seventh Circuit's interpretation of the 1983 version of Rule 11 provides a ready illustration of the dangers of ignoring the Advisory Committee Notes, and of the Enabling Act concerns that may arise during a Rule's interpretation. The 1983 amendments to Rule 11 were designed to minimize litigation abuses by defining more precisely the standards to be met by attorneys who signed litigation papers and by requiring sanctions for violations of those standards. Judges on the Seventh Circuit Court of Appeals applied the new rule with enthusiasm. "Lawyers practicing in the Seventh Circuit, take heed!" warned Judge Posner, in an early application of the amended Rule: "The rules, whether statutory or judge-made, designed to discourage groundless litigation are being and will continue to be enforced in this circuit to the hilt."

Indeed, in its zeal to dig the knife in, the Seventh Circuit arguably removed the hilt and fashioned a much longer, sharper blade than the drafters of amended Rule 11 had envisioned. The 1983 amendments to Rule 11 made sanctions mandatory upon a finding of violation and provided that "appropriate sanction $[\mathrm{s}]$... may include an order to pay to the other party ... the amount of the reasonable expenses incurred because of the filing of the pleading, motion, or other paper, including a reasonable attorney's fee." 179 The use of the term "sanction" suggests, and the Advisory Committee Note underscores, that the mandatory sanction was intended for deterrence, rather than to compensate the opposing party. ${ }^{180}$ Thus, the Note explained that the word "sanctions" was added to the caption of Rule 11

${ }^{178}$ Dreis \& Krump Mfg. Co. v. Int'l Ass'n of Machinists, Dist. No. 8, 802 F.2d 247, 255-56 (7th Cir. 1986) (reversing the district court's denial of sanctions, and remanding for an award of attorney's fees under FED. R. CIV. P. 11 and FED. R. APP. P. 38).

${ }^{179}$ FED. R. CIV. P. 11 (as amended effective Aug. 1, 1983). A redlined version of Rule 11, showing the changes made by the 1983 amendments, is reprinted at 97 F.R.D. 196-97 (1983).

180 This point has already been well made by others. See STEPHEN B. BURBANK, Rule 11 in TRANSITION: THE REPORT OF THE THIRD CiRCuIT TASK FORCE ON FEDERAL Rule of CIVIL PROCEDURE 11, at 11 (1989) (marshalling the evidence from the text and Note of the amendment to show that the goal of the Rule was deterrence, not compensation). I review the argument here because it provides a ready example of issues relating to the proper role of Advisory Committee Notes in interpretation (see infra Part III.B). 
to emphasize "a deterrent orientation in dealing with improper pleadings, motions or other papers." ${ }^{181}$ The Note justified the amendment in incentive-oriented terms, claiming that "Rule 11 has not been effective in deterring abuses" and arguing that the amended Rule "should discourage dilatory or abusive tactics and help to streamline the litigation process by lessening frivolous claims or defenses." ${ }^{182}$ Nowhere in the text or Note was it suggested that compensation was or should be a goal of sanctions under Rule 11 .

Undeterred (so to speak) by the text and Note of Rule 11, the Seventh Circuit transformed the Rule into a tort-like provision designed not merely to discourage violations but also to compensate injured parties. ${ }^{1 \$ 3}$ As Judge Easterbrook explained in Szabo Food Service, Inc. v. Canteen Corp., if a party "impose[s] costs on its adversary and the judicial system by violating Rule 11, it must expect to pay." ${ }^{184}$ Rule 11, in this view, "requires the court to impose a sanction-for the protection of the judicial process as much as to relieve the financial burden that baseless litigation imposes on the other side." ${ }^{, 185}$ The Szabo court made the tort analogy explicit, stating that the Rule's "reasonable inquiry" requirement "does not require steps that are not cost-justified," and arguing that the Rule includes both an objective componentwhich "effectively picks up the tort[] of abuse of process"-and a "subjective component"- which references "the tort[] of . . malicious prosecution." 186 Soon afterward, Judge Posner elaborated the tort

${ }^{181}$ FED. R. CIV. P. 11 advisory committee's note (1983), reprinted in 97 F.R.D. at 199-200.

182 Id., reprinted in 97 F.R.D. at 198.

${ }^{183}$ Stephen Burbank has previously called attention to this phenomenon. See Burbank, supra note 60, at 1959 (noting that Hays v. Sony Corp. and Szabo Food Service, Inc. v. Canteen Corp. "assimilat[e Rule 11] to no fewer than three torts").

The Seventh Circuit did, on occasion, recognize deterrence as a goal of Rule 11. See, e.g., Brown v. Fed'n of State Med. Bds., 830 F.2d 1429, 1438 (7th Cir. 1987) ("Compensation, although an important consideration, is not the only purpose underlying Rule 11. An even more important purpose is deterrence."). The court appeared, however, to contemplate that the goal of compensation would lead to larger sanctions, in at least some cases, than would be justified on grounds of deterrence alone. Compare Brown, 830 F.2d at 1439 ("In some cases, the district court may choose to give a small portion of the fees requested as a sanction. Compensation would not be the primary motivating force behind such a sanction; rather, deterrence of the frivolous litigation would be the court's purpose."), with id. at 1440 (holding that "[d]istrict courts should provide specific findings when awarding substantial compensatory sanctions").

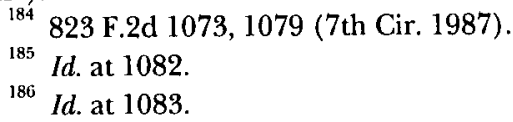


theme in Hays $v$. Sony Corp., reasoning that Rule 11 "imposes a negligence standard," and that "[r] estating the standard in negligence terms helps one to see that Rule 11 defines a new form of legal malpractice." ${ }^{187}$ In accordance with this view, the Hays court drew upon, inter alia, the Restatement (Second) of Torts, Prosser and Keeton on the Law of Torts, and a law review article on legal malpractice. ${ }^{188}$

In addition to conceptualizing Rule 11 as a font of tort liability, the Seventh Circuit recast the Rule as a fee-shifting provision. ${ }^{189}$ Thus, in Brown v. Federation of State Medical Boards the court explained that

[c]ompensation is one thrust of Rule $11 \ldots$ primarily because Rule 11 was designed to implement the "bad faith exception to the American Rule ... that in a system requiring each party to bear its own fees and costs, courts will ensure that each party really does bear the costs and does not foist expenses off on its adversaries." ${ }^{190}$

In Hays, the court relied on the premise that "Rule 11 is a fee-shifting statute" to justify borrowing procedures developed under fee-shifting provisions such as the Equal Access to Justice Act: ${ }^{191}$

a uniform body of law has grown up about such statutes entitling a party who successfully invokes the statute to obtain reasonable fees incurred in obtaining the statutory fees, plus reasonable fees in defending the award on appeal .... There is no reason to complicate this body of law by making an exception for Rule 11 fee-shifting.

The Seventh Circuit's analysis of Rule 11 as compensationoriented and as a fee-shifting provision did more than depart from the

${ }^{187} 847$ F.2d 412, 418 (7th Cir. 1988), overruled on other grounds by Cooter \& Gell v. Hartmarx Corp., 496 U.S. 384 (1990).

${ }^{188} I d$. at 419 (citing RESTATEMENT (SECOND) OF TORTS $\$ 299 \mathrm{~A} \mathrm{cmt.} \mathrm{g} \mathrm{(1965),}$ Prosser and Keeton on the LAW OF Torts 185 (W. Page Keeton ed., 5th ed. 1984), and Richard D. Bridgman, Legal Malpractice-A Consideration of the Elements of a Strong Plaintiff's Case, 30 S.C. L. REV. 213, 227-30 (1979)).

${ }^{189}$ Stephen Burbank has critiqued the Seventh Circuit's assertion in Hays that "Rule 11 is a fee-shifting statute." See Burbank, supra note 60, at 1947 ("Of course it is nothing of the sort....").

${ }^{190} 830$ F.2d 1429, 1437-38 (7th Cir. 1987) (second ellipsis in original) (quoting In $r e$ TCI Ltd., 769 F.2d 441, 446 (7th Cir. 1985)).

191 28 U.S.C. $\$ 2412$ (1994).

${ }^{192}$ Hays, 847 F.2d at 419 . In this passage, the Hays court cited Westmoreland $v$. CBS, Inc., 770 F.2d 1168, 1179 (D.C. Cir. 1985), which applied the amended Rule 11, and McDonald v. Schweiker, 726 F.2d 311, 313-14 (7th Gir. 1983), which applied the Equal Access to Justice Act, 28 U.S.C. \$ 2412(d). The Supreme Court subsequently rejected the argument that Rule 11 authorized a district court to award attorney's fees incurred in defending a Rule 11 award on appeal. See Cooter $\mathcal{F}^{\circ}$ Gell, 496 U.S. at 406 ("Rule 11 is more sensibly understood as permitting an award only of those expenses directly caused by the filing, logically, those at the trial level."). 
Rule's text and Note; it also cast sharply into question the validity of amended Rule 11 under the Rules Enabling Act. It is hard to see how a rule that must not "abridge, enlarge or modify any substantive right" ${ }^{\prime 193}$ could "define a new form of legal malpractice"194 or parallel the torts of malicious prosecution or abuse of process. Likewise, although fee-shifting statutes can serve a number of different goals, including that of deterring undesirable litigation conduct, ${ }^{195}$ they are often designed to affect both access to court and the enforcement of substantive legal rights ${ }^{196}$ - purposes which fall outside the scope of the Rules Enabling Act delegation. ${ }^{197}$ Indeed, similar concerns formed the core of the Rules Enabling Act challenge addressed by the Supreme Court in Business Guides, Inc. v. Chromatic Communications Enterprises, Inc. ${ }^{198}$ The petitioner argued that

\footnotetext{
19928 U.S.C. $\$ 2072($ b) (1994).

${ }^{194}$ Hays, 847 F.2d at 418.
}

${ }^{195}$ See, e.g., Thomas D. Rowe, Jr., The Legal Theory of Attorney Fee Shifting: A Critical Overview, 1982 DUKE L.J. 651, 660-61 (noting that "deterrence of aggravated misconduct" is one aspect of the "punitive" rationale for fee-shifting, and that "[p]erhaps the leading example of a fee shifting practice reflecting [fee-shifting for abuse of process] is the federal courts' bad faith exception to the American rule for cases in which a party refuses to recognize a clear legal right or engages in bad faith conduct in litigation").

${ }^{96}$ See id. at 653 (noting that a fee-shifting provision can be justified by, inter alia, "the public usefulness of advancing a particular type of claim," "a desire to affect the relative strengths of the parties," or the provision's "expected or actual economic incentive effects"). For example, the Equal Access to Justice Act's statements of findings and purpose indicate that the Act was designed to alleviate concerns that certain persons "may be deterred from seeking review of, or defending against, unreasonable governmental action because of the expense involved." Equal Access to Justice Act, Pub. L. No. 96-481, § 202, 94 Stat. 2321, 2325 (1980); see also Rowe, supra note 195, at 664 (arguing that Congress appears to have intended the Equal Access to Justice Act to address a perceived imbalance of resources in certain types of litigation between private parties and the federal government); John J. Sullivan, Note, The Equal Access to Justice Act in the Federal Courts, 84 Colum. L. REv. 1089, 1092-93 (1984) (quoting legislative history to support proposition that the goals of the Act included "remov[ing] the "economic deterrents to contesting government action"” and enlisting private litigants in “'refining and formulating public policy").

${ }^{197}$ As Stephen Burbank and Linda Silberman have noted,

[ $t$ ] he experience with Rule 11 reveals how delicate is the balance between the use of attorney fee-shifting to deter litigation misconduct and its use to effect social policy concerning access to court. Indeed, Congress' ultimate decision in the securities legislation to include provisions for mandatory and presumptive fee-shifting sanctions for violations of Rule 11 rather than fee-shifting tied to the result, makes the point eloquently.

Stephen B. Burbank \& Linda J. Silberman, Civil Procedure Reform in Comparative Context: The United States of America, 45 AM. J. COMP. L. 675, 694-95 (1997) (citation omitted). 198498 U.S. 533 (1991). 
Rule 11, to the extent that it imposes on represented parties an objective standard of reasonableness, exceeds the limits of the Court's power in two ways: (1) It authorizes fee shifting in a manner not approved by Congress; and (2) it effectively creates a federal tort of malicious prosecution, thereby encroaching upon various state law causes of action.

No member of the Court attempted to argue, in response, that a feeshifting, tort-style Rule 11 would pass muster under the Rules Enabling Act; instead, a majority of the Court dismissed the Rules Enabling Act challenge on the grounds that "Rule 11 is not a fee-shifting statute" $" 200$ and that " $[t]$ he main objective of the Rule is not to reward parties who are victimized by litigation; it is to deter baseless filings and curb abuses." ${ }^{201}$ For the latter proposition the Court cited its earlier decision in Cooter $\mathcal{E}^{2} \mathrm{Gell}$, which had in turn relied upon the Advisory Committee Note to support the conclusion that "the central purpose of Rule 11 is to deter baseless filings in district court." 202

Remarkably, even after the Supreme Court's rejection of the compensation approach, the Seventh Circuit persisted in applying it. $^{203}$ Perhaps in response to such behavior, the 1993 amendments inserted an explicit reference to the deterrence rationale into the text of Rule 11, which now provides that the sanction imposed "shall be limited to what is sufficient to deter repetition of such conduct or comparable conduct by others similarly situated." ${ }^{204}$ Such an amendment would have been unnecessary had courts heeded the 1983 Notes' emphasis on deterrence. The deterrence/compensation debate thus demonstrates the effects of disregarding the Advisory Committee Notes. It also illustrates that the interpretation of a Rule may be colored by concerns about the Enabling Act's prohibition on Rules that abridge, enlarge, or modify substantive rights. I take up those two issues in the sections that follow.

199 Id. at 551-52.

${ }^{200} I d$. at 553 (quoting Cooter \& Gell v. Hartmarx Corp., 496 U.S. 384, 409 (1990)).

201 Id

${ }^{202}$ Cooter $\mathcal{E}$ Gell, $^{2} 496$ U.S. at 393 (citing FED. R. CrV. P. 11 advisory committee's note (1983)); see also Pavelic \& LeFlore v. Marvel Entm't Group, 493 U.S. 120, 126 (1989) ("The purpose of the provision in question, however, is not reimbursement but 'sanction'....").

${ }^{203}$ See Brandt v. Schal Assocs., Inc., 960 F.2d 640, 645-46 (7th Cir. 1992) (acknowledging the Supreme Court's statement that Rule 11's purpose is deterrence rather than reimbursement, but citing Seventh Circuit decisions from the mid-1980s for the proposition that "[c]ase law acknowledges compensation as another important objective and purpose for Rule 11").

${ }^{204}$ FED. R. CIV. P. 11 (c) (2) (1993). 


\section{A. The Limits of the Delegation}

Because the Enabling Act limits the permissible scope of the Rules, the interpretation of a Rule should either yield a meaning that obeys the Act's constraints or result in invalidation of the Rule. Accordingly, interpreters should take care to enforce the Act's admonition that the rules "shall not abridge, enlarge or modify any substantive right." ${ }^{, 205}$ Here, however, a problem arises. Decades ago, Justices Black and Douglas noted "the embarrassment of having to sit in judgment on ... rules which we have approved and which as applied in given situations might have to be declared invalid." ${ }^{206}$ Such embarrassment might help to explain the fact that the Court has never invalidated a Rule for violating the Enabling Act. To the contrary, the Court has created a presumption of validity for the Rules based on their transmission by the Court and on Congress's failure to enact legislation to prevent them from taking effect. The Court has balanced this presumption, however, by holding that the Rules are to be interpreted so as to avoid Enabling Act problems. This avoidance doctrine is preferable to the enforcement of a Rule that exceeds the scope of the delegation; but it is a second-best alternative. Ideally, the Court should abandon the presumption of Rule validity and directly enforce the terms of the delegation.

The Court's notorious failure to police the Act's prohibition on Rules affecting substantive rights-combined with a blurring of the distinction between substance and procedure ${ }^{207}$ - has led many commentators to view the prohibition as a matter of merely theoretical in-

205 28 U.S.C. $\$ 2072$ (1994).

${ }^{206}$ Order of Jan. 21, 1963, 374 U.S. 865, 870 (1963) (Black \& Douglas, JJ.). (The quoted statement referred to questions of the Rules' constitutionality; but the concern applies equally to questions of validity under the Enabling Act.)

${ }^{207}$ See, e.g., Bone, supra note 119 , at 914 ("It is simply not possible to separate out a domain of purely technical procedure divorced from substance...."); see also, e.g., Mistretta v. United States, 488 U.S. 361, 392 (1989) (noting "the logical morass of distinguishing between substantive and procedural rules" and admitting that "this Court's rulemaking under the enabling Acts has been substantive and political in the sense that the rules of procedure have important effects on the substantive rights of litigants" (citation omitted)). Nonetheless, careful analysis can provide guidelines for assessing compliance with the Enabling Act's restrictions, without necessitating "a particularistic and after-the-fact inquiry into policies animating competing legal prescriptions." Burbank, supra note 11, at 1191. For example, Stephen Burbank has argued that Rules overstep the bounds of the Act if their creation "necessarily involves the consideration of public policy-policies extrinsic to the process of litigation," as when a Rule has "predictable and identifiable" effects on rights recognized under substantive law or creates "remedial rights that predictably or identifiably affect personal liberty or the use and enjoyment of property." Id. at 1128, 1190 . 
terest. $^{208}$ Soon after the promulgation of the initial set of Rules, the Court-faced in Sibbach $v$. Wilson $\mathcal{E}^{2}$ Co. with the contention "that Rules 35 and 37 work a major change of policy and that this was not intended by Congress" ${ }^{209}$ - set a presumption of validity for Rules promulgated under the Act: "Evidently the Congress felt the rule was within the ambit of the statute as no effort was made to eliminate it from the proposed body of rules, although this specific rule was attacked and defended before the committees of the two Houses." The difficulties with such a view are evident: Congressional inaction might indicate approval, but it may also stem from lack of interest, from indecision, or from the fact that other matters took precedence. ${ }^{211}$ As Justice Frankfurter argued in dissent: "Having due regard to the mechanics of legislation and the practical conditions surrounding the business of Congress when the Rules were submitted, to draw any inference of tacit approval from non-action by Congress is to appeal to unreality." "212 Unreality, however, has its uses, and the Court has continued to rely upon the presumption of validity, ${ }^{213}$ which it

208 See, e.g., Stephen B. Burbank, Sanctions in the Proposed Amendments to the Federal Rules of Civil Procedure: Some Questions About Power, 11 HOFSTRA L. REv. 997, 1006-07 (1983) ("As long as Sibbach v. Wilson $\mathcal{E}^{2}$ Co. remains law and the Court that promulgates Federal Rules and amendments has the final word on their validity, disputations regarding validity and invalidity are likely to be of purely academic interest . ...").

209312 U.S. 1, 14 (1941).

${ }^{210} I d$. at 15 (citation omitted).

211 See ESKRIDGE, supra note 136, at 247 ("What does the inaction establish? There are as many reasons for Congress not to act as there are members of Congress-ranging from complete disinterest to indecision, higher priority for other measures, dislike of one feature of the bill, or approval of existing law." (footnote omitted)).

${ }^{212}$ Sibbach, 312 U.S. at 18 (Frankfurter, J., dissenting).

${ }^{213}$ See, e.g., Burlington N. R.R. Co. v. Woods, 480 U.S. 1, 6 (1987) (unanimous decision) ("[T] he study and approval given each proposed Rule by the Advisory Committee, the Judicial Conference, and this Court, and the statutory requirement that the Rule be reported to Congress for a period of review before taking effect ... give the Rules presumptive validity under both the constitutional and statutory constraints." (citations omitted)).

The Court revealed both doubts concerning, and a continuing allegiance to, the presumption of validity when it dismissed, as improvidently granted, the writ of certiorari in Ticor Title Insurance Co. v. Brown, 511 U.S. 117 (1994) (per curiam). The certified question in Ticor asked "whether a federal court may refuse to enforce a prior federal class action judgment, properly certified under Rule 23, on grounds that absent class members have a constitutional due process right to opt out of any class action which asserts monetary claims on their behalf." Id. at 120-21 (quoting Petition for Certiorari, at i). Although this question would be "of no general consequence if, whether or not absent class members have a constitutional right to opt out of such actions, they have a right to do so under the Federal Rules of Civil Procedure"-i.e., if damages class actions could be certified only "under Rule 23(b) (3), which permits opt- 
elaborated in Hanna v. Plumer. "When a situation is covered by one of the Federal Rules," a court can refuse to apply the Rule "only if the Advisory Committee, this Court, and Congress erred in their prima facie judgment that the Rule in question transgresses neither the terms of the Enabling Act nor constitutional restrictions." ${ }^{214}$ Unsurprisingly, the Court has never found a promulgated Rule to transgress the limitations of the Enabling Act. ${ }^{215}$

Despite the Court's unwillingness to scrutinize Rules for compliance with the substantive rights restriction, it has made some attempts to reconcile the presumption of validity with the constraints of the Enabling Act. The majority in Business Guides quoted Hanna's language on the presumption of validity, but it also devoted three pages of its opinion to an analysis of the contention that "imposing sanctions against a represented party that did not act in bad faith violates the Rules Enabling Act." ${ }^{216}$ Although the Court rejected the Enabling Act challenge, it did so by interpreting Rule 11 to avoid some of the possi-

out, and not under Rules 23(b) (1) and (b) (2), which do not"-the Ticor parties were bound by a prior lower court decision holding that the class was properly certified under Rules 23(b) (1) and (2), so that in Ticor"the alternative of using the Federal Rules instead of the Constitution as the means of imposing an opt-out requirement for this settlement [was] no longer available." Id. at 121. The Court expressed reluctance to address the constitutionality of Rule 23, arguing that "[i]f the Federal Rules, which generally are not affirmatively enacted into law by Congress, are not entitled to that great deference as to constitutionality which we accord federal statutes, they at least come with the imprimatur of the rulemaking authority of this Court." Id. at 121-22 (citations omitted). Thus, the Court expressed concern that if it assumed that Rule 23 permits non-opt-out damages class actions and proceeded to assess the constitutionality of the Rule so construed, it might "approve, in the mistaken deference to prior Supreme Court action and congressional acquiescence, action that neither we nor Congress would independently think constitutional." Id. at 122. The Court did not explain why-having noted the dangers of the presumption of validity-it would nonetheless apply it. Ticor, though it concerned constitutional rather than Enabling Act limitations, provides an illustration of the Court's preference for resolving questions of Rule validity through construction, rather than invalidation, of the Rule. Infra text accompanying notes $216-22$.

${ }^{214} 380$ U.S. 460,471 (1965) (citing Sibbach, 312 U.S. at 13-15). But see Miss. Publ'g Corp. v. Murphree, 326 U.S. 438, 444 (1946) ("The fact that this Court promulgated the rules as formulated and recommended by the Advisory Committee does not foreclose consideration of their validity, meaning or consistency.").

${ }^{215}$ The Court has not always been so self-deferential. See Meek v. Centre County Banking Co., 268 U.S. 426, 434 (1925) (holding invalid the Court's General Order in Bankruptcy No. 8 on the ground that " $[\mathrm{t}]$ he authority conferred upon this court by $\$$ 30 of the Bankruptcy Act to prescribe all necessary rules, forms and orders as to procedure and for carrying the Act into effect, is plainly limited to provisions for the execution of the Act itself, and does not authorize additions to its substantive provisions").

${ }^{216}$ Bus. Guides, Inc. v. Chromatic Communications Enters., Inc., 498 U.S. 533, 551-54 (1991). 
ble Enabling Act concerns: thus, it reaffirmed that the Rule "is not a fee-shifting statute," that the Rule's "main objective" is not compensation but deterrence, and that district courts should "resist the temptation to use sanctions as substitutes for tort damages." in Ortiz $v$. Fibreboard Corp., ${ }^{218}$ the Court rejected an expansive view of the non-opt-out classes authorized by Rule 23(b)(1)(B), based in part on Enabling Act constraints. Noting that "the text of Rule 23 (b) (1) (B) is on its face open to a more lenient ... concept," the Court argued that its narrower interpretation "minimizes potential conflict with the Rules Enabling Act, and avoids serious constitutional concerns." $^{219}$

Minimizing conflict with the Enabling Act is a worthy goal, but it can invite departure from a Rule's text and Notes. Last Term, in Semtek International Inc. v. Lockheed Martin Corp., ${ }^{220}$ a unanimous Court dismissed the contention that Rule $\mathbf{4 1}$ governs the claim-preclusive effect of a federal court judgment, noting that "such a rule would arguably violate the jurisdictional limitation of the Rules Enabling Act." 221 The Court thereby avoided invalidating the Rule; but as Stephen Burbank has explained, the Court's interpretation strains the Rule's text and contravenes its history. ${ }^{222}$ The awkwardness of such interpretations is underlined, moreover, to the extent that the Court views the Enabling Act limitation as serving federalism, and not sepa-

${ }^{217}$ Id. at 553; see also Kamen v. Kemper Fin. Servs., Inc., 500 U.S. 90, 96 (1991) (unanimous decision) (citing an Enabling Act limitation as the ground for holding that Rule 23.1 does not create a demand requirement in shareholder derivative suits).

Three of the Business Guides dissenters argued that the avoidance rationale instead supported their position: "Whether or not Rule 11 as construed by the majority exceeds our rulemaking authority, these concerns weigh in favor of a reasonable, alternative interpretation." Business Guides, 498 U.S. at 568 (Kennedy, J., joined by Marshall \& Stevens, JJ., dissenting).

${ }^{218} 527$ U.S. 815 (1999).

219 Id. at 842; see also Amchem Prods., Inc. v. Windsor, 521 U.S. 591, 629 (1997) ("Rule 23, which must be interpreted with fidelity to the Rules Enabling Act and applied with the interests of absent class members in close view, cannot carry the large load CCR, class counsel, and the District Court heaped upon it.").

${ }^{220} 531$ U.S. 497 (2001).

221 Id. at 503. The Court concluded that Rule 41(b) simply bars refiling of the same claim in the same federal district court, and does not govern the claim-preclusive effect of the judgment in other courts. Semtek, 531 U.S. at 505-06.

${ }^{222}$ Stephen B. Burbank, Semtek, Forum Shopping and Federal Common Law, 77 NOTRE DAME L. REV. 101, 113-20 (2002). Admittedly, the Semtek Court's interpretation of Rule 41 (b) is unlikely to work serious mischief. In other instances, however, departures from a Rule's text and Notes may not be so innocuous. See, e.g., supra text accompanying notes 179-203 (describing the Seventh Circuit's interpretations of Rule 11). 
ration of powers, concerns: in cases where that vision guides Enabling Act scrutiny, the Court's avoidance doctrine can produce Rules that have one meaning in diversity cases and another in federal question cases. $^{223}$

In instances where a Rule as drafted plainly violates the Enabling Act, then, the Court's unwillingness to invalidate Rules poses a dilemma. According the text its apparent meaning will result in the application of a Rule that, by impermissibly affecting substantive rights, violates the Enabling Act. Avoiding Enabling Act problems by departing from the text and Notes, however, contravenes the principlewhich I argue derives from the Enabling Act's structure-that the Court should not rewrite a Rule through interpretation. Admittedly, avoidance-driven revisions may seem less intrusive than policy-driven revisions: the driving principle behind avoidance is fidelity to the Enabling Act, not indulgence of the Court's own policy preferences, and it might be argued that rulemakers who exceed their authority should not be heard to complain when the Court rewrites their handiwork. As with other judicial revisions of the Rules, however, the structure of the rulemaking process urges caution. Invalidation of an amended Rule would return the situation to the status quo prior to that amendment's promulgation; by contrast, redrafting the Rule on avoidance grounds creates a Rule that never proceeded through the rulemaking process. ${ }^{224}$ Just as a Court's ability to veto a proposed amendment does not grant it the power to enact such an amendment through interpretation, the Court's duty to invalidate Rules that transgress the Enabling Act limitation does not authorize it to revise a Rule in the name of avoiding Enabling Act problems.

As Business Guides illustrates, not all Enabling Act issues concern Rules that plainly transgress the Act's substantive rights limitations. Where the text and Notes permit two interpretations, one of which would violate the Enabling Act, the Court's avoidance doctrine may properly apply. In cases like Semtek, however-where avoidance distorts a Rule's text or contradicts its Notes-the Court should abandon

${ }^{223}$ See Stephen B. Burbank, Of Rules and Discretion: The Supreme Court, Federal Rules and Common Law, 63 NOTRE DAME L. REv. 693, 701, 705 (1988) (concluding, based on Walker v. Armco Steel, 446 U.S. 740 (1980), a diversity case, and West v. Conrail, 481 U.S. 35 (1987), a federal question case, that the Court believes Rule 3 to have "two plain meanings").

${ }^{224}$ Cf. Frederick Schauer, Ashwander Revisited, 1995 SUP. CT. Rev. 71, 74 (“[I]t is by no means clear that a strained interpretation of a federal statute that avoids a constitutional question is any less a judicial intrusion than the judicial invalidation on constitutional grounds of a less strained interpretation of the same statute."). 
the presumption of validity and hold that the Rule violates the Act. ${ }^{225}$

\section{B. Advisory Committee Notes}

Those who view the Court's role in rulemaking as conferring broad interpretive discretion are apt to dismiss the Advisory Committee Notes as nonbinding. Judge Moore, for instance, argues that the dispositive interpretive consideration should be, not the Notes, but the promulgating Court's own understanding of the Rule-even if that understanding was never publicly expressed. ${ }^{226}$ The Court itself has not explicitly relied on such a bold rationale, but it consistently refuses to accord the Notes binding authority-despite ascribing such authority to similar sources in other contexts. A review of the role of the Notes in the rulemaking process, however, demonstrates that the Advisory Committee Notes possess distinctive claims to authority, based both on the terms of the Enabling Act and on the practicalities of rulemaking. ${ }^{227}$

\section{Intentionalism and the Notes}

An intentionalist analysis of the Rules faces two initial questions. First, the interpreter must determine which of the institutional players in the rulemaking process, if any, might be ascribed an intent that should give meaning to the Rule. Second, assuming the choice of one such body, the usual issues arise concerning the aggregation of intents within a multimember entity. Consideration of these questions indicates that the Advisory Committee Notes provide a legitimate source

${ }^{225}$ Although the discussion in the text focuses on the role of the Supreme Court in interpreting Rules, I also believe that lower federal courts should choose invalidation over avoidance when the latter would twist the text of a Rule or contradict the pertinent Advisory Committee Note. Although lower courts might hesitate to hold that a Rule approved by the Supreme Court violates the Rules Enabling Act, such a holding is preferable to an interpretation that contravenes the clear import of the text and Notes. Moreover, in some instances a district court might hold a Rule invalid "as applied" (rather than facially invalid), in which event the district court need not be seen as striking down an application necessarily envisioned by the Supreme Court when the latter approved the Rule for transmission to Congress.

${ }^{226}$ See Moore, supra note 3, at 1094 ("It is possible that the Court, in adopting a particular Rule, had a different view of purpose or policy that may or may not have been expressed publicly and that should be considered when interpreting a Rule.").

${ }^{227}$ Some other potential interpretive sources are open to criticisms similar to those advanced in the debates over statutory interpretation. Thus, although the drafting history of the Rules amendments has become more readily available, its use may provoke objections similar to those customarily leveled at reliance on statutes' legislative histories. 
of interpretive authority.

Despite Supreme Court rhetoric to the contrary, ${ }^{228}$ it would-as noted above-be problematic to assign an intent to Congress with respect to Rules promulgated under the Enabling Act. It is, of course, true that the rulemakers may be influenced by their perception of preferences within Congress. ${ }^{229}$ Thus, the rulemakers may consider changes to the Rules in order to forestall a dissatisfied Congress from drafting legislation. Similarly, the prospect of congressional action may be the most significant incentive for the rulemakers to observe the bounds of the Act's delegation. ${ }^{230}$ Even if Congress's anticipated responses influence the decisions of the rulemakers, however, the resulting Rules cannot be seen as a product of congressional action, ${ }^{231}$ and they provide no reliable indication of any particular congressional intent. Finally, to the extent that Congress's failure to prevent a Rule from taking effect might indicate some legislators' approval of the Rule, the materials set before Congress would generally provide the

${ }^{228}$ For example, the Court employed such rhetoric in Irwin v. Department of Veterans Affairs, 498 U.S. 89, 92-93 (1990), when it cited Federal Rule of Civil Procedure 5 as evidence that "Congress has endorsed [the] practice" of service upon a party's attorney-notwithstanding the fact that Congress had never taken any legislative action with respect to Rule 5. Similarly, the dissenting Justices in Plaut v. Spendthrift Farm, Inc., 514 U.S. 211 (1995), contended that the "clear congressional intent" expressed in Federal Rule of Civil Procedure 60(b), id. at $257 \mathrm{n} .9$ (Stevens, J., joined by Ginsburg, J., dissenting), provided an example of an instance "'in which Congress has attempted to set aside the final judgment of an Article III court by retroactive legislation,'" id. at 252 (Stevens, J., joined by Ginsburg, J., dissenting) (quoting majority opinion). The Plaut majority neglected to make the obvious response-that Rule 60 (b), which was promulgated (and amended) pursuant to the Rules Enabling Act without any congressional action at all, was not an example of congressional legislation. Instead, the majority implicitly adopted the dissent's view of Rule $60(\mathrm{~b})$ as an example of congressional action and attacked the dissent's Rule $60(\mathrm{~b})$ argument for, inter alia, "inver[ting] the statutory presumption regarding retroactivity [that] statutes do not apply retroactively unless Congress expressly states that they do." Id. at 236-37 (majority opinion). And in Gasperini v. Center for Humanities, Inc., 518 U.S. 415 (1996), Justice Scalia concluded his dissent by complaining of "the Court's precedent-setting disregard of Congress's instructions in Rule 59," id. at 469 (Scalia, J., joined by Rehnquist, C.J., and Thomas, J., dissenting)-despite the fact that Rule 59 had never been the subject of congressional action.

${ }^{229}$ Cf. Bone, supra note 119 , at 924 (noting that "a public choice analysis should treat court rulemaking as a strategic game among the Advisory Committee, Congress, and the various interest groups").

${ }^{230}$ See, e.g., Burbank, supra note 208, at 1006-07 (positing that under the current framework of rulemaking and rule interpretation, "the remedy, if any, to overreaching [by the rulemakers] will come by way of congressional action").

${ }^{231}$ See, e.g., id. at 1011 ("It should be obvious that I do not regard the "laying before' provision of the Rules Enabling Act as a substitute for, or as equivalent to, congressional action."). 
best indication of what such legislators thought they were approving. Those materials, as noted above, are the text of the Rule and its accompanying Note. ${ }^{232}$

In contrast to Congress, the Supreme Court has (at least in form) an active role in the promulgation process. Based on this role, proponents of Supreme Court interpretive discretion have argued that the Court may disregard the Notes in favor of its own view of the Rules' intended purposes. ${ }^{233}$ Such an argument, however, is triply erroneous. First, the extent to which a majority of the Court even considers the merits of a proposed Rule is unclear. The disclaimers given over the years by Justices Frankfurter, ${ }^{234}$ Powell, ${ }^{235}$ Stewart, ${ }^{296}$ and Rehnquist, ${ }^{237}$ as well as the protestations of Justices Black and Douglas, ${ }^{238}$ strongly suggest that the Court has often functioned merely as a "conduit" for rules amendments. Second, even if the Court considers the substance of a Rule when voting to approve it, the Court's laconic orders and transmittal letters give no indication of its understanding of the Rule. ${ }^{239}$ Since the Court is obviously not the only decision

${ }^{232}$ Cf. Imwinkelried, supra note 1, at 411 (arguing that the Notes to the Federal Rules of Evidence should be entitled to "significant weight" because, inter alia, "the notes physically accompanied the draft rules through every stage of congressional consideration").

Other pieces of drafting history, such as transmittal letters from the Advisory Committee or the Standing Committee, may also accompany the text and Notes of the Rule when they are sent to the Court and then to Congress. In such instances, the letters, like the text and Notes, might prove informative; but-unlike the Notes-such documents would not necessarily have accompanied the proposal during the earlier stages of public comment and redrafting.

${ }^{293}$ See Bauer, supra note 3, at 728 ("[S]ince it is the Supreme Court which had the responsibility for promulgating the Rule under scrutiny, the historical views of the Advisory Committee-which merely drafted the Rule-of its meaning should be entitled only to limited weight."); Moore, supra note 3, at 1093-94 (contending that "the comments of the Advisory Committee and the other bodies involved in the promulgation process" are "useful," but that the Supreme Court "should not be bound" by them when it interprets the Rules).

${ }^{234}$ See supra note 116 (quoting Justice Frankfurter's statement concerning the 1946 amendments).

${ }^{235}$ See supra note 117 and accompanying text (quoting the statement of Justice Powell, joined by Justices Stewart and Rehnquist, dissenting from adoption of the 1980 amendments to discovery rules).

${ }_{236}^{236}$ See id. (same).

${ }^{237}$ See id. (same); supra note 118 and accompanying text (quoting Chief Justice Rehnquist's letter transmitting the 1993 amendments to Congress).

${ }^{238}$ See supra notes 114-15 (citing dissents by Justices Black and/or Douglas from the Court's promulgation of various rules and amendments).

${ }^{239}$ Of course, dissents from orders of transmittal provide an indication of the understanding of the dissenter, but there is no evidence that such an understanding is 
maker in the process, the rulemaking framework forecloses the possibility that the promulgating Court's unexpressed understanding of a Rule should govern the Rule's future interpretation. Suppose the Court transmits Rule "X" to Congress only because the Court believes that the Rule actually means "not X." The "not X" understanding, which appears neither in the text nor the Note of the proposed Rule, has not been considered, let alone approved, by the Advisory Committee, the public, the Standing Committee, or the Judicial Conference, ${ }^{240}$ and therefore it should not control future interpretations of the Rule. Third, the Court that interprets a Rule will not always be the same Court that promulgated it. Thus, even if it were legitimate for the Court to apply its prior unexpressed view of the Rule, there would be substantial doubt as to the Court's ability to reconstruct that view. As with Congress, the most reliable indicators of the Court's intent will be the items it considered and transmitted: the text and Notes of the Rule.

On occasion, the Court suggests that the relevant question is what the Advisory Committee intended. In Business Guides, for instance, the Court explained its rejection of an alternate reading of Rule 11 by stating that "there is no indication that this is what the Advisory Committee intended," and that it would not adopt such a reading "absent a compelling indication in the text that the Advisory Committee intended such a result." ${ }^{241}$ Moreover, though such statements might

shared by the majority.

${ }^{240}$ Indeed, given the terse style of the Court's typical transmittal letters, it is also unlikely that Congress will be made aware of the "not X" understanding. Even if the Court explains the "not X" view in its transmittal letter to Congress, however, that will not cure the fact that the prior stages of the rulemaking process included no mention of the "not X" interpretation.

${ }^{241} 498$ U.S. 533, 544, 546 (1991). In Business Guides, the Court held that Rule 11's "objective standard of reasonable inquiry" applied not only to attorneys and pro se litigants, but also to "represented parties who sign papers or pleadings." Id. at 554. Although Rule 11's signing requirement applied only to attorneys and unrepresented parties, its certification provision stated that " $[\mathrm{t}]$ he signature of an attorney or party constitutes a certificate by the signer" that, inter alia, "the signer has read" the paper and "to the best of the signer's knowledge, information, and belief formed after reasonable inquiry [the paper] is well grounded in fact." FED. R. CIV. P. 11 (1983). In turn, Rule 11 's sanctions provision required that " $[\mathrm{i}] \mathrm{f}$ a . . paper is signed in violation of this rule, the court ... shall impose upon the person who signed it, a represented party, or both, an appropriate sanction." Id. The Court, having noted its resolve to give the Rules "their plain meaning," Business Cuides, 498 U.S. at 540 (quoting Pavelic \& LeFlore v. Marvel Entm't Group, 493 U.S. 120, 123 (1989)), argued that the certification and sanctions provisions "seem[] plain: A party who signs a pleading or other paper without first conducting a reasonable inquiry shall be sanctioned." Id. at 541 . Even in situations where a party is not required to sign a paper, the Court reasoned, if the party 
seem to suggest that the Advisory Committee's intent could be shown only by the text of the Rule, the Business Guides Court relied upon the Notes to resolve a further question. ${ }^{242}$

No matter which body's understanding is at issue, then, the most logical evidence of such intent can be found in the Rule's text and Advisory Committee Notes. Moreover, the Notes avoid the aggregation problem that an intentionalist analysis might otherwise present. Judith Resnik has cautioned that articles later published by individual members of the original Advisory Committee may not reflect the views of the Committee as a whole, because "it is difficult to establish the existence of shared intentionality." ${ }^{243}$ By contrast, the text and Notes of

does sign the paper the signature triggers Rule 11's certification provision. Id. at 544 . To rule otherwise, in the Court's view, would require rewriting the certification provision "to mean 'attorney or unrepresented party." Id. The Court refused "to adopt this unnatural reading," because it found "no indication" that such a reading was "what the Advisory Committee intended." Id. Two pages later, the Court adopted a clear statement requirement concerning Advisory Committee intent, based on the Court's view of an underlying premise of Rule 11 :

Business Guides asks that we construe Rule 11 in a way that would render the signatures on these statements risk free. Because this construction is at odds with the Rule's general admonition that signing denotes merit, we are loath to do so absent a compelling indication in the text that the Advisory Committee intended such a result.

Id. at 546

${ }^{242}$ The Court's conclusion that signing subjected parties to Rule 11's certification provisions required it to decide "whether the certification standard for a party is the same as that for an attorney." Id. at 548. Here, again, the Court proclaimed itself bound by the "plain language," and supported by the policies, of Rule 11. Id. at 54849. Rule 11 , the Court reasoned, "states unambiguously that any signer must conduct a 'reasonable inquiry' or face sanctions.... Even if we were convinced that a subjective bad faith standard would more effectively promote the goals of Rule 11, we would not be free to implement this standard outside of the rulemaking process." Id. Moreover, "as a policy matter, ... [q]uite often it is the client, not the attorney, who is better positioned to investigate the facts supporting a paper or pleading." Id. at 549. Thus, "[a] contrary rule would establish a safe harbor such that sanctions could not be imposed where an attorney, pressed to act quickly, reasonably relies on a client's careless misrepresentations." Id. at 549-50. Despite its emphasis on the Rule's "plain language," however, the Court stated-based on the Notes' observation that the applicable standard "'is one of reasonableness under the circumstances," - that the reasonable inquiry required of a represented party might differ from that required of an attorney. Business Guides, 498 U.S. at 550-51 (quoting FED. R. CIV. P. 11 advisory committee's note (1983)).

${ }^{249}$ Judith Resnik, The Domain of Courts, 137 U. PA. L. REv. 2219, 2221 \& n.4 (1989) (citing Charles E. Clark, Fundamental Changes Effected by the New Federal Rules I, 15 TENN. L. REV. 551, 560 (1939), and Edson R. Sunderland, The New Federal Rules, 45 W. VA. L.Q. 5, 30 (1938)). In an earlier article, Resnik had discussed this point in more detail: Of course, I do not (and could not) claim to know the thoughts of the diverse individuals ... who comprised the Advisory Committee that prepared drafts of the Rules for the Supreme Court, nor do I assume that they shared a collective 
a Rule cannot be forwarded for promulgation without a majority of votes in each decision-making body (the Advisory Committee, the Standing Committee, the Judicial Conference, and the Supreme Court). The language of a proposal approved and forwarded by a rulemaking body presumably reflects the intent of those who vote in favor of it; and the current rulemaking framework indicates that Notes are as much the product of the formal drafting and approval process as is the text of the Rule. As discussed in Part I.E above, the Notes are mandated by the Enabling Act and accompany the text through each stage of circulation, comment, revision, and approval. ${ }^{244}$ Although Justice Scalia has argued that "there is no certainty that either we or [Congress] read [the Notes], nor is there any procedure by which we formally endorse or disclaim them,"245 his own dissent from the Court's transmittal of the 1993 amendments illustrates that he, at any rate, considers an objectionable Note to be a basis for dissenting from the promulgation of a Rule. ${ }^{246}$

"intent." Indeed, from the history of the drafting debates (and from what one knows of life in general), it must be supposed that there was a fair amount of disagreement within the group. Further, not all the voices of those on the Advisory Committee can be heard distinctly today. The academics on the Committee have left the richest record; the practicing lawyers' views are less accessible.

Judith Resnik, Failing Faith: Adjudicatory Procedure in Decline, 53 U. CHI. L. REV, 494, 498-99 (1986) (footnotes omitted).

Despite these conceptual problems, the Court sometimes relies heavily on the views of an Advisory Committee Reporter. See, e.g., Amchem Prods., Inc. v. Windsor, 521 U.S. 591, 613-19 (1997) (construing Rule 23 and relying repeatedly on language from articles published in 1967 and 1969 by the Reporter for the Advisory Committee that drafted the 1966 amendments to the Rules).

${ }^{244}$ See Noah, supra note 135 , at 313 ("[T] mitted to Congress in tandem with the text of the rules in the same way that committee reports accompany a bill to the floor ....").

${ }^{245}$ Tome v. United States, 513 U.S. 150, 168 (1995) (Scalia, J., concurring in part and concurring in the judgment) (discussing FED. R. EVID. 801 advisory committee's note). Although Evidence Rule 801 (at issue in Tome) had been enacted via legislation, Justice Scalia appears to have directed his critique both at Notes to Rules promulgated without congressional interference and at Notes to Rules that were legislatively enacted. See id. at 167 (Scalia J., concurring in part and concurring in the judgment) ("It is the words of the Rules that have been authoritatively adopted-by this Court, or by Congress if it makes a statutory change.").

${ }^{246}$ Justice Scalia's asserted bases for dissent included the Note as well as the text of the proposed Rule, apparently on the assumption that the Note's admonitions would be binding: quoting the Note (not the text), Justice Scalia argued that "the likelihood that frivolousness will even be challenged is diminished by the proposed Rule, which restricts the award of compensation to 'unusual circumstances,' with monetary sanctions 'ordinarily' to be payable to the court." Order of Apr. 22, 1993, 146 F.R.D. 404, 508-09 (Scalia, J., joined by Thomas, J., dissenting in part) (quoting FED. R. CIV. P. 11 advisory 


\section{Textualism and the Notes}

The fact that the Notes proceed through the approval process along with the text also helps to meet textualist objections to their use. Admittedly, the Notes perform functions for which statutory texts are not generally used; but-seen in the light of their creation-the Notes in some ways resemble text more than legislative history. Thus, as will be seen, the criticisms that textualists have leveled against the use of such history lack the same force when applied to the Notes.

As discussed in Part I.E, the Notes, in addition to informing the rulemaking process itself, can serve a number of functions postpromulgation: they can explain the reasons behind the amendment, discuss the Rule's application to particular situations, consider the amendment's relation to surrounding law, and provide practice guides for judges and lawyers to use when applying the Rule. In some of these respects, the Notes appear similar to the Comments to the Uniform Commercial Code ("Official Comments"); the Notes' mode of adoption, however, differs significantly from that of the Official Comments. The National Conference of Commissioners on Uniform State Laws, in conjunction with the American Law Institute, supervises and approves the creation of proposed UCC provisions; each provision becomes law only when adopted by the legislature of the relevant state. $^{247}$ Unlike the Rules, which in most instances become law by default (through congressional inaction), the UCC provisions must be enacted affirmatively by the state legislatures; moreover, the legislatures do not always have the Official Comments before them at the

committee's note (1993)); see also id. at 509 (Scalia, J., joined by Thomas, J., dissenting in part) (objecting that "the commentary makes it clear that even when compensation is granted it should be granted stingily-only for costs 'directly and unavoidably caused by the violation"" (quoting FED. R. CIV. P. 11 advisory committee's note (1993))). Eileen Scallen has noted that it is

highly improbable that United States Supreme Court Justices would transmit proposed rules ... to Congress without reading both the rules and their accompanying commentary. Moreover, there certainly is a means of disapproving both the Notes and the proposed rules themselves. When the Chief Justice transmits the rules to Congress, it is with an explanatory letter that can even contain dissenting views. Justice Scalia himself has made use of this to make his opinions very clear.

Eileen A. Scallen, Interpreting the Federal Rules of Evidence: The Use and Abuse of the Advisory Committee Notes, 28 LOY. L.A. L. REV. 1283, 1300 (1995) (footnotes omitted).

${ }^{247}$ See generally JAMES J. WHITE \& RoberT S. SUMmers, UNIFORM COMMERCIAL COdE: Secured Transactions 1-7 (5th ed. 2000); Alan Schwartz \& Robert E. Scott, The Political Economy of Private Legislatures, 143 U. PA. L. REV. 595, 600-02 (1995) (describing roles of the ALI and the NCCUSL in drafting and promulgation of UCC provisions). 
time when they enact the text. ${ }^{248}$ Thus, although it appears that courts give the Official Comments substantial weight, ${ }^{249}$ that practice may be vulnerable from a textualist perspective.

By contrast, the main textualist objections to the use of legislative history lack bite when applied to the Advisory Committee Notes. Some textualists argue, with respect to statutes, that the constitutional requirements of bicameralism and presentment ${ }^{250}$ deny binding authority to any text other than that passed by both houses of Congress and signed by the President. ${ }^{251}$ In the case of the Rules, of course, Congress has delegated its authority to the rulemakers, and the only bicameralism involved in the adoption of most Rules is that of bicameral inertia. Moreover, the Enabling Act specifically directs the creation of the Notes and requires that the Notes accompany any recommendations made by the Advisory or Standing Committees; ${ }^{252}$ obviously, the Constitution includes no such requirement concerning the transmittal of legislative history. Textualists also can impugn legislative history by pointing to the difficulty of aggregating the intent of individual legislators, ${ }^{253}$ and by claiming that the legislators may not have been aware of the pertinent legislative history. ${ }^{254}$ By contrast, the

${ }^{248}$ See WHITE \& SuMmERS, supra note 247 , at 14 ("In some states the comments were not placed before the enacting body prior to adoption of the Code. Indeed, some of the present comments were not even in existence at the time the section to which they are now appended was adopted.").

${ }^{249}$ See 1 William D. HaWkland, Uniform Commercial Code Series $\$$ 1-102:10, at 1-52 (1982) ("The case law indicates that courts are more influenced by the Official Comments than by any other thing, except decided cases on the same matter." (citations omitted)).

${ }^{250}$ U.S. CONST. art. I, $\$ 7$.

${ }^{251}$ This argument has been criticized on the ground that even if the bicameralism and presentment requirements indicate that only the statutory text is "the law," they do not preclude a court from using other sources to help determine that text's meaning. See, e.g., ESKRIDGE, supra note 119, at 230 (noting that critics of Scalia's textualist arguments have conceded that legislative history is not "authoritative in the same way the statutory text is authoritative: the latter is and has the force of law, the former is, at best, evidence of what the law means").

${ }^{252}$ See 28 U.S.C. $\$ 2073$ (d) (1994) ("[T] he body making [a] recommendation shall provide a proposed rule, an explanatory note on the rule, and a written report explaining the body's action, including any minority or other separate views.").

${ }^{253}$ See, e.g., Bank One Chi., N.A. v. Midwest Bank \& Trust Co., 516 U.S. 264, 280 (1996) (Scalia, J., concurring in part and concurring in the judgment) ("Legislative history that does not represent the intent of the whole Congress is nonprobative; and legislative history that does represent the intent of the whole Congress is fanciful.").

${ }^{254}$ See, e.g., Wis. Pub. Intervenor v. Mortier, 501 U.S. 597, 620 (1991) (Scalia, J., concurring in the judgment) (noting that pertinent portions of the relevant committee reports, "though they dominate our discussion today, constituted less than a quarter-page of the 82-page House Agriculture Committee Report, and less than a half- 
active examination, and, at times, amendment of the Notes by the Advisory Committee and the Standing Committee, as well as the likelihood that the Notes receive scrutiny from at least some members of the Judicial Conference, the Supreme Court, and (occasionally) Congress, indicate that those who considered and approved the text of the Rule also considered and approved the accompanying Note.

Other textualist bogeys, similarly, fail to haunt the use of the Notes. The textualist concern that lobbyists might influence congressional aides to hide rent-seeking language in corners of voluminous committee reports $^{255}$ has little application to Notes, which are generally brief (at least as compared to congressional committee reports) and which are likely to be read carefully at several stages in the approval process. Moreover, the Notes are less susceptible than legislative history to charges of indeterminacy and malleability; ${ }^{256}$ the Notes' relative brevity, the comparative care with which they are drafted, ${ }^{257}$ and the fact that each proposed amendment is ultimately accompanied by only one Note, make the Notes less likely to support multiple interpretations on a given question. Finally, while legislative history

page each of the 74-page Senate Agriculture Committee Report, the 46-page Senate Commerce Committee Report, and the 73-page Senate Agriculture Committee Supplemental Report"); Begier v. IRS, 496 U.S. 53, 67 (1990) (Scalia, J., concurring in the judgment) (dismissing statement of House floor manager on the basis that "we do not know for sure that Representative Edwards' words were even uttered on the floor rather than inserted into the Congressional Record afterwards").

${ }^{255}$ Take for example this objection by Justice Scalia:

As anyone familiar with modern-day drafting of congressional committee reports is well aware, the references to the cases were inserted, at best by a committee staff member on his or her own initiative, and at worst by a committee staff member at the suggestion of a lawyer-lobbyist; and the purpose of those references was not primarily to inform the Members of Congress what the bill meant . . . , but rather to influence judicial construction.

Blanchard v. Bergeron, 489 U.S. 87, 98-99 (1989) (Scalia, J., concurring in part and concurring in the judgment)

${ }^{256}$ See, e.g., Conroy v. Aniskoff, 507 U.S. 511,519 (1993) (Scalia, J., concurring in the judgment) (borrowing Judge Harold Leventhal's description of "the use of legislative history as the equivalent of entering a crowded cocktail party and looking over the heads of the guests for one's friends").

${ }^{257}$ Of course, the Notes on occasion exhibit inconsistencies. For example, Stephen Burbank has observed that the Note to the 1983 amendments to Rule 11 recognized that the 1983 amendment to Rule 11's sanctions provisions "represent[ed] an expansion of existing authority," while the Note to the 1983 amendments to Rule 26 stated that the corresponding sanctions provision added to Rule 26 in 1983 "merely codifie [d] existing authority and require[d] the courts to exercise it." Burbank, supra note 208 , at 1001 . 
may be expensive to research, ${ }^{258}$ the Notes are readily available on Westlaw.

\section{The Court's Use of the Notes and Comparable Materials}

The distinctions discussed above may help to explain the Court's frequent resort to Notes in construing the Rules. During the last fifteen years-despite the Court's internal debate over textualism in statutory interpretation-all the Justices have made liberal use of the Notes. $^{259}$ As will be seen, however, the Court generally avoids suggesting that the Notes have binding effect; instead, it prefers indeterminate formulations, such as the statement that the Notes are "of weight" in the interpretation of the Rules. Not only is this view incompatible with the Notes' role in the rulemaking process, but it conflicts with the Court's treatment of two analogous interpretive guides: the commentary to the United States Sentencing Guidelines, and agencies' interpretations of their own legislative rules.

Since a number of the Justices are generally open to the use of legislative history, their use of Advisory Committee Notes is not surprising. Justice Scalia, however, is noted for his opposition to the use of legislative history in statutory construction; not only does he generally eschew the use of such history when writing his own opinions, ${ }^{260}$

${ }^{258}$ See, e.g., Crosby v. Nat'l Foreign Trade Council, 530 U.S. 363, 391 (2000) (Scalia, J., joined by Thomas, J., concurring in the judgment) (criticizing the Court's reliance on legislative history on the ground that such history "must be researched and discussed by counsel-which makes appellate litigation considerably more time consuming, and hence considerably more expensive, than it need be"); Conroy v. Aniskoff, 507 U.S. 511, 519 (1993) (Scalia, J., concurring in the judgment) (reasoning that the use of legislative history in construing an unambiguous statute "undermines the clarity of law, and condemns litigants (who, unlike us, must pay for it out of their own pockets) to subsidizing historical research by lawyers").

259 See, e.g., Amchem Prods., Inc. v. Windsor, 521 U.S. 591, 614-17, 625 (1997) (citing Notes to Federal Rule of Civil Procedure 23); Bracy v. Gramley, 520 U.S. 899, 909 (1997) (unanimous decision) (citing Note to Habeas Corpus Rule 6); United States v. Hyde, 520 U.S. 670, 676-77 (1997) (unanimous decision) (citing Note to Federal Rule of Criminal Procedure 32); United States v. Olano, 507 U.S. 725, 731, 736-37 (1993) (quoting Advisory Committee Notes to Federal Rules of Criminal Procedure 23 and 52); Pioneer Inv. Servs. Co. v. Brunswick Assocs. Ltd. P'ship, 507 U.S. 380, 389 n.4, $390-$ 91 \& n.5 (1993) (citing Note to Federal Rule of Bankruptcy Procedure 9006(b) and Notes to former Bankruptcy Rule 10-401(b)); Crosby v. United States, 506 U.S. 255, 260 (1993) (unanimous decision) (citing Note to Federal Rule of Criminal Procedure 43).

${ }^{260}$ Although Justice Scalia has not always adhered to the strictures of the textualist approach, see, e.g., William N. Eskridge, Jr., The New Textualism, 37 UCLA L. REV. 621, 658 (1990) ("Probably all of the Justices are willing to consult relevant legislative history if the statutory text is genuinely ambiguous or open-textured."), it is his predomi- 
but he also writes separately-in cases where he agrees with the result reached by the Court-to disassociate himself from the Court's use of legislative history. ${ }^{261}$ Nonetheless-despite his predominantly textual-

nant approach to interpreting statutes, see, e.g., Schacter, supra note 139 , at $642 \mathrm{n} .270$ ("Justice Scalia has not entirely foreclosed resort to legislative history in circumstances that present sufficient statutory ambiguity but seems reluctant to find such circumstances presented."); id. at 658 n.144 ("Even Justice Scalia said in Chan, 109 S. Ct. at 1683 , that he might consult legislative history 'to elucidate a text that is ambiguous,' but there appear to be relatively few texts that he finds 'ambiguous."').

${ }^{261}$ See, e.g., Crosby, 530 U.S. at 390 (Scalia, J., joined by Thomas, J., concurring in the judgment) ("[E]ven if all of the Court's invocations of legislative history were not utterly irrelevant, I would still object to them, since . . . [t] he only reliable indication of [the intent of the majority of both Houses of Congress] is the words of the bill that they voted to make law."); United States v. Estate of Romani, 523 U.S. 517, 535 (1998) (Scalia, J., concurring in part and concurring in the judgment) (criticizing the Court's reliance on the history of unenacted legislation); Dunn v. CFTC, 519 U.S. 465, 480-81 (1997) (Scalia, J., concurring in part and concurring in the judgment) (refusing to join portions of the Court's opinion that discuss legislative history); Bank One Chi., N.A. v. Midwest Bank \& Trust Co., 516 U.S. 264, 279 (1996) (Scalia, J., concurring in part and concurring in the judgment) ("I agree with the Court's opinion, except that portion of it which enters into a discussion of ' $[t]$ he drafting history of $\$ 4010$."); Thunder Basin Coal Co. v. Reich, 510 U.S. 200, 219 (1994) (Scalia, J., joined by Thomas, J., concurring in part and concurring in the judgment) (refusing to join a section of the Court's opinion that "consists of a discussion of the legislative history of the Federal Mine Safety and Health Amendments Act of 1977"); Conroy v. Aniskoff, 507 U.S. 511, 518 (1993) (Scalia, J., concurring in the judgment) (complaining that "the Court feels compelled to demonstrate that its holding is consonant with legislative history, including some dating back to 1917"); Begier v. IRS, 496 U.S. 53, 70 (1990) (Scalia, J., concurring in the judgment) ("If the Court had applied to the text of the statute the standard tools of legal reasoning, instead of scouring the legislative history for some scrap that is on point..., it would have reached the same result it does today ...."); Taylor v. United States, 495 U.S. 575, 603 (1990) (Scalia, J., concurring in part and concurring in the judgment) ("I join in the Court's opinion except for Part II, which examines in great detail the statute's legislative history."); Jett v. Dallas Indep. Sch. Dist., 491 U.S. 701, 738 (1989) (Scalia, J., concurring in part and concurring in the judgment) ("I join Parts I and IV of the Court's opinion, and Part III except insofar as it relies upon legislative history."); Green v. Bock Laundry Mach. Co., 490 U.S. $504,527-29$ (1989) (Scalia, J., concurring in the judgment) (conceding that because a literal reading of Federal Rule of Evidence 609(a)(1) would produce an absurd result, legislative history may be consulted "to verify that what seems to us an unthinkable disposition ... was indeed unthought of," but refusing to join Court's opinion because the latter uses legislative history to determine "not merely ... that the word 'defendant' cannot have been meant literally, but [also] what, precisely, the Rule does mean"); Blanchard v. Bergeron, 489 U.S. 87, 97-99 (1989) (Scalia, J., concurring in part and concurring in the judgment) (joining the Court's opinion "except that portion which rests upon detailed analysis of" lower court cases cited in statute's legislative history); United States v. Taylor, 487 U.S. 326, 344 (1988) (Scalia, J., concurring in part) ("I join the opinion of the Court except Part II-A, which is largely devoted to establishing, through the floor debate in the House, [points which] seem to me so utterly clear from the text of the legislation that there is no justification for resort to the legislative history."); INS v. Cardoza-Fonseca, 480 U.S. 421, 452 (1987) (Scalia, J., con- 
ist approach to statutory interpretation-Justice Scalia frequently joins, or even writes, opinions that rely upon Advisory Committee Notes. In Cooter $\mathcal{E}^{\mathcal{V}}$ Gell, for example, Justice Scalia joined the majority's opinion, which relied on the Notes to resolve two of the three issues presented. As to the standard for appellate review, the Court relied on Rule 11's text, ${ }^{262}$ Note, ${ }^{263}$ and purposes ${ }^{264}$ to hold that a district judge's Rule 11 determinations should be reviewed for abuse of discretion. ${ }^{265}$ With respect to the scope of sanctions, the Court refused to extend Rule 11 to authorize the award of attorney's fees incurred while defending a Rule 11 sanction on appeal, reasoning that "[n]either the language of Rule 11 nor the Advisory Committee Note suggests that the Rule could require payment for any activities outside the context of district court proceedings." ${ }^{266}$ Likewise, in 1991 Justice Scalia joined a part of the dissent's opinion in Business Guides that relied on the text of Rule 11, "the Rule's history[,] and the commentary that accompanied its adoption" to argue that represented parties should not be subject to the Rule's certification requirement. ${ }^{267}$ In the dissenters' view, "the drafters of Rule 11 intended to bind [only] those whose signatures are provided for in the Rule itself." ${ }^{268}$ The dissent found negative evidence of this intent in the Advisory Committee Notes:

If the drafters of the 1983 amendments had intended a radical departure from prior practice by imposing duties on represented parties that before had been imposed only on attorneys, one might expect discussion

curring in the judgment) (refusing to join Court's opinion because, inter alia, the Court "undertakes an exhaustive investigation of . . . legislative history").

${ }^{262}$ Cooter \& Gell v. Hartmarx Corp., 496 U.S. 384, 400 (1990) ("In directing the district court to impose an 'appropriate' sanction, Rule 11 itself indicates that the district court is empowered to exercise its discretion.").

${ }^{263}$ See id. (quoting the Note's statement that "a district court 'has discretion to tailor sanctions to the particular facts of the case"').

${ }^{264}$ See id. at 404 ("The district court is . . best situated to determine when a sanction is warranted to serve Rule 11's goal of specific and general deterrence.").

265 Id. at 405.

260 Id. at 406 . The Court bolstered this conclusion by noting that Federal Rule of Appellate Procedure 38 governed litigants' conduct on appeal, thus "plac[ing] a natural limit on Rule 11 's scope." Id. at 407. The Court argued, moreover, that "[1] imiting Rule 11's scope in this manner accords with the policy of not discouraging meritorious appeals," $i d$. at 408, and the Court observed that "[a]s Rule 11 is not a fee-shifting statute, the policies for allowing district courts to require the losing party to pay appellate, as well as district court attorney's fees, are not applicable," id. at 409.

${ }_{267}^{67} 498$ U.S. 538, 555 (1991) (Kennedy, J., joined by Marshall, Stevens, \& Scalia, J., dissenting).

${ }^{268}$ Id. at 556. 
of the change in the Advisory Committee's Notes accompanying the 1983 amendments. But the Notes say nothing of the kind. . . The failure to mention the signature of a represented party is a startling omission if such a signature could violate the Rule.

The dissonance between Justice Scalia's approaches to Rules and to statutes appeared to strike him in 1995, when he refused to join a part of Justice Kennedy's opinion in Tome $v$. United States because he objected to the plurality's use of Advisory Committee Notes to show "the 'purpose,' . . . or 'intent,' . . of the draftsmen" of Federal Rule of Evidence $801(\mathrm{~d})(1)(B) .{ }^{270}$ Justice Scalia admitted his own prior use of such Notes-confessing that "I have previously acquiesced in ..., and indeed myself engaged in ..., similar use of the Advisory Committee Notes"-but concluded that "[m]ore mature consideration has persuaded me that is wrong." 271 This conversion, however, did not last very long: ${ }^{272}$ in cases decided after Tome, Justice Scalia has joined eight opinions that make substantive use of Notes in interpreting Rules, ${ }^{273}$

269 Id. at 558-59.

${ }^{270} 513$ U.S. 150, 167 (1995). (Scalia, J., concurring in part and concurring in the judgment). Perhaps because Evidence Rule 801 was enacted by Congress in the same form proposed by the rulemakers, Justice Scalia's opinion discussed Rules promulgated by the rulemakers and Rules enacted by Congress as though they presented similar interpretive issues.

${ }^{271}$ Id. Justice Scalia made three arguments against reliance on the Notes. First, "[i]t is the words of the Rules that have been authoritatively adopted-by this Court, or by Congress if it makes a statutory change." Id. Second, "[1]ike a judicial opinion and like a statute, the promulgated Rule says what it says, regardless of the intent of its drafters." Id. at 168. Finally, "there is no certainty that either we or [Congress] read [the Notes], nor is there any procedure by which we formally endorse or disclaim them." Id. These arguments are addressed in Parts III.B.1 and B.2 above.

${ }^{272}$ In one subsequent case, the Court distinguished Tome and refused to take a position on the appropriate weight to be accorded to the Notes. See Libretti v. United States, 516 U.S. 29, 41 (1995) ("The Tome plurality treated the Advisory Committee's Notes on Federal Rule of Evidence 801(d)(1)(B) as relevant evidence of the drafters' intent as to the meaning of that Rule... In contrast, Libretti seeks to use the Note appended to Rule 31 to elucidate the meaning of an entirely distinct Rule. We cannot agree....").

${ }^{273}$ See Becker v. Montgomery, 532 U.S. 757, 767 n.4 (2001) (unanimous decision) (using a Note to illustrate the operation of Federal Rule of Civil Procedure 11 and interpreting Federal Rule of Appellate Procedure 3 in light of its purpose as explained in the Note); Ortiz v. Fibreboard Corp., 527 U.S. 815, 833-35 \& n.15, 838, 841-45 \& nn. 20-21, 864 (1999) (relying heavily on Notes in interpreting Federal Rule of Civil Procedure 23); Cunningham v. Hamilton County, Ohio, 527 U.S. 198, 208 \& n.5 (1999) (unanimous decision) (citing a Note to underscore the purpose of Federal Rule of Civil Procedure 37); United States v. Beggerly, 524 U.S. 38, 42-43, 45 (1998) (unanimous decision) (stating that " $[\mathrm{t}]$ he Advisory Committee notes confirmed" the survival of the "independent action" under the 1946 amendment to Rule $60(\mathrm{~b})$ ); Amchem Prods., Inc. v. Windsor, 521 U.S. 591, 614-17, 625 (1997) (relying extensively on Notes 
and has even argued in dissent that a Note contradicts the majority's interpretation of a statute. ${ }^{274}$

Admittedly, the position that Justice Scalia took in Tome contemplates the use of Notes as "persuasive scholarly commentaries," a view that would permit occasional citation. ${ }^{275}$ However, Justice Scalia has also joined opinions that explicitly use the Notes to decipher, and implement, the Advisory Committee's intent with respect to a particular Rule. For example, the Court in Ortiz v. Fibreboard Corp. spent more than three pages reconstructing "what the Advisory Committee must have assumed would be at least a sufficient set of conditions to justify binding absent members of a class under Rule 23(b)(1)(B)," studded its opinion with references to what the Advisory Committee

in construing Federal Rule of Civil Procedure 23); Bracy v. Gramley, 520 U.S. 899, 909 (1997) (unanimous decision) (quoting a Note with respect to purpose of Habeas Rule 6); United States v. Hyde, 520 U.S. 670, 676-77 (1997) (unanimous decision) (relying on the explanation given in a Note to Federal Rule of Criminal Procedure 32(e)); id. at 680 (rejecting a party's argument based on the Note to Federal Rule of Criminal Procedure 32(b) (3), because Rule 32(b) (3) "obviously does not deal at all with motions to withdraw guilty pleas, and any comments in the Advisory Committee's Notes to this Rule dealing with plea withdrawal could not alter the meaning of Rules 11 and 32(e) as we have construed them"); Henderson v. United States, 517 U.S. 654, 658 n.5, 662-64, 669 n.17 (1996) (quoting the 1937 and 1993 Advisory Committee Notes to Federal Rule of Civil Procedure 4).

${ }^{274}$ Hohn v. United States, 524 U.S. 236, 255 (1998) (Scalia, J., joined by Rehnquist, C.J., O'Connor \& Thomas, JJ., dissenting). Justice Scalia argued that 28 U.S.C. $\$ 2253$, as amended by the Antiterrorism and Effective Death Penalty Act of 1996, Pub. L. 104-132, 110 Stat. 1214, requires a prisoner seeking review of a final order in a habeas proceeding to seek a certificate of appealability from "circuit judges in their individual capacity," rather than from "the Court of Appeals as such." Hohn, 524 U.S. at 255 (Scalia, J., joined by Rehnquist, C.J., O'Connor \& Thomas, JJ., dissenting). To bolster this argument, Justice Scalia observed that the 1967 Advisory Committee Notes to Federal Rule of Appellate Procedure 22 "explicitly state that ' 28 U.S.C. \$ 2253 does not authorize the court of appeals as a court to grant a certificate of probable cause." Id. (Scalia, J., joined by Rehnquist, C.J., O'Connor \& Thomas, JJ., dissenting) (quoting FED. R. APP. P. 22 advisory committee's note (1967)). (The 1967 Advisory Committee Notes referred to a prior version of $\$ 2253$ that contained language similar, in pertinent part, to that at issue in Hohn.)

${ }^{275}$ See, e.g., Weisgram v. Marley Co., 528 U.S. 440, 449 n.5, 450 (2000) (unanimous decision) (quoting the 1963 Advisory Committee's Notes to Federal Rule of Civil Procedure 50 to show that Rule 50's failure expressly to address the question presented (whether a court of appeals that determines that a jury verdict cannot be sustained due to erroneous admission of evidence may order entry of judgment for verdict loser) "was not inadvertent"); Carlisle v. United States, 517 U.S. 416, 432 (1996) (Scalia, J.) (using a "but see" cite to Note to Federal Rule of Criminal Procedure 33 to contradict what Justice Scalia asserts is an implication of the dissent's reasoning).

${ }^{276} 527$ U.S. 815,838 (1999) (referring to "the limited fund class action as understood by the drafters of Rule 23"); see also id. at 838-41 (discussing conditions contemplated by the Advisory Committee). 
"assumed,",277 "underst[oo]d[]" ${ }^{, 278}$ and "intended,", Committee "looked cautiously at," " have thought ... surprising," ${ }^{282}$ was "concern [ed]" about, ${ }^{283}$ or "did not envision." ${ }^{284}$ Likewise, the Court's opinion in Amchem Products, Inc. $v$. Windsor addressed the question of what cases "the Advisory Committee sought to cover" in Federal Rule of Civil Procedure 23(b) (3) ${ }^{285}$ The Amchem Court observed that "[w] hile the text of Rule 23(b) (3) does not exclude from certification cases in which individual damages run high, the Advisory Committee had dominantly in mind vindication of 'the rights of groups of people who individually would be without effective strength to bring their opponents into court at all."'286 The Court did note that, despite the Advisory Committee's advice that mass tort cases "are 'ordinarily not appropriate' for class treatment ... [,] the text of the Rule does not categorically exclude mass tort cases from class certification, and District Courts, since the late 1970's, have been certifying such cases in increasing number."${ }^{, 287}$ The Court nonetheless made clear that the text of the Rule was not the only pertinent consideration: "The Committee's warning ... continues to call for caution when individual stakes are high and disparities among class members great." ${ }^{288}$

277 See id. at 841-42 ("The Advisory Committee, and presumably the Congress in approving subdivision (b) (1) (B), must have assumed that an action with these characteristics would satisfy the limited fund rationale cognizable under that subdivision."); see also id. at 844 ("It is simply implausible that the Advisory Committee . . would have uncritically assumed that mandatory versions of such class actions, lacking such protections, could be certified under Rule 23(b) (1)(B).").

Id. at 842 .

${ }^{279}$ Id. at 843; see also id. at $844 \mathrm{n} .21$ (expressing "doubt that the Advisory Committee would have intended liberality in allowing such a circumscribed tradition to be transmogrified by operation of Rule 23(b)(1)(B) into a mechanism for resolving the claims of individuals not only against the fund, but also against an individual tortfeasor").

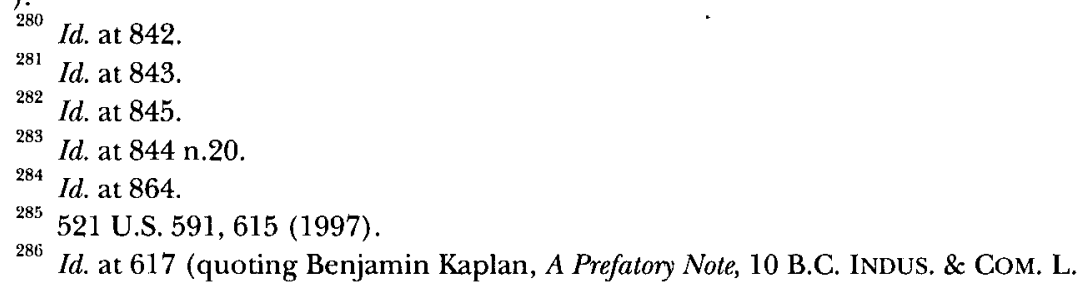
REV. 497, 497 (1969)). Benjamin Kaplan was the Reporter to the Advisory Committee that proposed the 1966 amendments to Rule 23, and the Court's opinion in Amchem cited his views repeatedly. Id. at 613-17.

${ }^{287}$ Id. at 625 (quoting FED. R. CIV. P. 23 advisory committee's note (1966)).

${ }^{288}$ Id. The Court's reliance on the views of the Advisory Committee is also reflected in its frequent citations to the Notes. See id. at 614-17, 625. 
In one respect, however, Justice Scalia's comparison of the Notes to "scholarly commentaries" seems to be an accurate reflection of the Court's approach. Though the Court is often willing to rely heavily on the Notes, it has never held them to be binding authority; instead, it prefers to state vaguely that the construction given to a Rule by its Note is "of weight" in the analysis. ${ }^{289}$ This view is problematic, because it permits courts to discount the Notes when it seems convenient to do so. ${ }^{290}$ Thus, the Court's unwillingness to treat the Notes as binding authority invites the criticisms (similar to those Justice Scalia has leveled at legislative history) ${ }^{291}$ that reliance on the Notes is mere "makeweight" and does not constrain the Court.

The Court's treatment of the Notes also contrasts with its handling of analogous materials. In Stinson v. United States, the Court held that commentary to the United States Sentencing Guidelines "that interprets or explains a guideline is authoritative unless it violates the Constitution or a federal statute, or is inconsistent with, or a plainly erroneous reading of, that guideline."292 The Court's explanation for this holding underscores the Guidelines commentary's similarity to the Advisory Committee Notes:

The functional purpose of commentary (of the kind at issue here) is to assist in the interpretation and application of [the Guidelines], which are within the [Sentencing] Commission's particular area of concern and expertise and which the Commission itself has the first responsibility to formulate and announce. In these respects this type of commentary is akin to an agency's interpretation of its own legislative rules ....

According this measure of controlling authority to the commentary is

${ }^{289}$ See, e.g., Torres v. Oakland Scavenger Co., 487 U.S. 312, 315-16 (1988) (citing FED. R. APP. P. 3 advisory committee's note (1967)); Schiavone v. Fortune, 477 U.S. 21 , 31 (1986) (citing FED. R. CIV. P. 15 advisory committee's note (1966)).

${ }^{290}$ The Seventh Circuit's treatment of the deterrence/compensation issue (with respect to the 1983 version of Rule 11) provides an illustration. See supra text accompanying notes $179-97$.

291 See, e.g., Bank One Chi., N.A. v. Midwest Bank \& Trust Co., 516 U.S. 264, 280 (1996) (Scalia, J., concurring in part and concurring in the judgment) ("[L]egislative history is in any event a makeweight; the Court really makes up its mind on the basis of other factors."); id. at 282 n.2 (Scalia, J., concurring in part and concurring in the judgment) (concluding that "legislative history has produced what it usually produces: more questions rather than more answers"); Thunder Basin Coal Co. v. Reich, 510 U.S. 200, 219 (1994) (Scalia, J., joined by Thomas, J., concurring in part and concurring in the judgment) (asserting that legislative history is "an omnipresent makeweight for decisions arrived at on other grounds"); Wis. Pub. Intervenor v. Mortier, 501 U.S. 597, 621 (1991) (Scalia, J., concurring in the judgment) (arguing that legislative materials "are a forensic rather than an interpretive device, to be invoked when they support the decision and ignored when they do not").

${ }^{202} 508$ U.S. 36, 38 (1993) (unanimous decision). 
consistent with the role the Sentencing Reform Act contemplates for the Sentencing Commission. The Commission, after all, drafts the guidelines as well as the commentary interpreting them, so we can presume that the interpretations of the guidelines contained in the commentary represent the most accurate indications of how the Commission deems that the guidelines should be applied to be consistent with the Guidelines Manual as a whole as well as the authorizing statute. ${ }^{293}$

The Stinson Court distinguished Advisory Committee Notes from Guidelines commentary, reasoning that the latter can be "issued well after the guideline it interprets ha[s] been promulgated," and arguing that it would be incongruous for the Sentencing Commission to "announce some statement of initial intent" only after the expiration of the report-and-wait process for congressional review of proposed Guidelines. ${ }^{234}$ However, this distinction suggests, if anything, that the Notes should be entitled to more deference than Guidelines commentary, because the Notes invariably accompany the proposed Rule throughout the approval process.

Similarly, adherence to the Notes would avoid problems such as those created by the Court's doctrine of deference to agency interpretations of legislative rules. The doctrine, as expressed in Bowles $v$. Seminole Rock $\mathcal{E}^{2}$ Sand Co., accords an agency's interpretation of a regulation that it has created "controlling weight unless [the interpretation] is plainly erroneous or inconsistent with the regulation., ${ }^{295} \mathrm{John}$ Manning has argued that such deference raises a problem of "selfdelegation": "when a lawmaker controls the interpretation of its own laws, an important incentive for adopting transparent and self-limiting rules is lost because any discretion created by an imprecise, vague, or ambiguous law inures to the very entity that created it." ${ }^{296}$ Moreover, deference "reduces the efficacy of notice-and-comment rulemaking" by "permit[ting] the agency to promulgate imprecise or vague rules and to settle upon or reveal their actual meaning only when the agency implements its rule through adjudication," ${ }^{, 297}$ and also raises problems of notice, to the extent that regulated parties "have [no] clear picture of relevant legal requirements until such parties have offended them.".298 By contrast, if the Advisory Committee Notes are

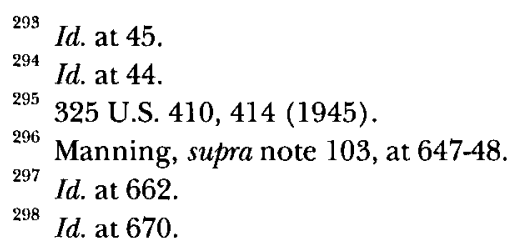


given binding effect, they could limit courts' future discretion (to the extent that they clarify or give specificity to the text of the Rules); increase the value of the notice-and-comment process (by explaining aspects of the proposed amendments); and further the goal of notice (by providing litigants and judges with an accessible source of guidance concerning the application of the Rules).

The analysis above thus supports the view that the Court should extend to Advisory Committee Notes the same deference that it has granted to Guidelines commentary and to an agency's interpretation of its legislative rules. Such an approach would mean that a court interpreting a Rule should always consult the Note as well as the text and should attempt to construe the text and Note so that they are consistent. Where the text and Note are irreconcilable, the text should trump the Note; but otherwise, the Note should be given binding effect.

\section{CONCLUSION}

The seeming paradox referenced in this Article's title-that the Enabling Act's delegation of rulemaking power actually limits the Court's interpretive latitude-arises from, and is explained by, the nature of the delegation. The limits of the delegation also impel the Article's doctrinal conclusions: that the Enabling Act's scope constraints should be enforced by invalidating the offending Rule, where necessary, rather than by applying an avoidance-based interpretation that distorts the Rule; and that courts should give effect to Advisory Committee Notes unless the Notes conflict with the text of the Rule. Such an approach would bring the interpretation of Rules into line with the structure that produces them and would demonstrate the judicial branch's awareness of the responsibility, as well as the authority, conferred by the Enabling Act delegation. In a time when "the court rulemaking model is under siege," ${ }^{299}$ clearer judicial recognition of that responsibility might offer a chance of greater permanency for the rulemaking process.

299 Bone, supra note 119 , at 888. 
* * * * * * * 